\title{
Turizm Problemolojisi: Bilgi Üretmenin Özdüşünümselliği
}

Tourism Problemology: Reflexivity Of Knowledge Making*

\author{
Kun LAi ${ }^{* \star}$, Jun $\mathbf{L i}^{\star \star}$, Noel SCOTT ${ }^{\star \star *}$ \\ ** Sun Yat-sen University, Çin \\ *** Griffith University (Gold Coast Campus), Avustralya
}

\section{Türkçeye çeviren:}

\section{Engin BAYRAKTAROĞLU****}

****Arş. Gör., Anadolu Üniversitesi, Turizm Fakültesi, 03200, Tepebaşı, Eskişehir.

E-posta: enginbayraktaroglu@anadolu.edu.tr.

\section{MAKALE BILGILERI}

Anahtar sözcükler:

Problemoloji, Bilgi üretimi,

Özdüşünümsellik, Araştırma toplu-

luğu, Kuramsallaştırma.
Key words:

Problemology, Knowledge production, Reflexivity, Research community, Theorizing.

\section{$\ddot{O Z Z}$}

Turizm bilgisi üretim sürecinin temelinde problemlerin yatıyor olmasına ragmen, turizm problemlerine ya da turizm problemolojisine münhasır, sistematik ve derinlemesine bir araştırma yapılmamıştır. Bu çalışma turizm problemolojisinin doğasını keşfetmeye ve bu boşluğu doldurmaya çalıșması açısından bir ilktir. Çalıșma kapsamında kuramsal model geliștirilmiș ve $\mathbf{2 1 2}$ Çinli turizm araștırmacısı üzerinde kısmen test edilmiștir. Sonuçlara göre araştırmacılar turizm problemlerini çözüm bekleyen zorluklar ya da çelişkiler olarak görmektedir. Dahası kişisel/ çevresel faktörler araştırmacıların problemlere yönelik anlayıșını etkilemektedir. Ayrıca etkilenen bu anlayıș da, araștırmanın erken evresinde araștırmacıların problem seçimini ve değerlendirmesini etkilemektedir. Calıșma, turizm problemlerini, önemini ve henüz üzerinde durulmamış olan turizm bilgisi üretiminin özdüşünümselliğini öne çıkarmaktadır.

\section{ABSTRACT}

Although problems are a fundamental dynamics of tourism knowledge production, a systematic, exclusive, and in-depth study of tourism problems or tourism problemology has been overlooked. This study, which represents the first time to examine the nature of tourism problemology, aims to fill this gap. A theoretical model is developed and partially tested through a survey of 212 Chinese tourism researchers. Results show that researchers generally consider problems as difficulties or contradictions that require resolution. Moreover, personal/environmental factors influence the researchers' understanding of problems, and such understanding further affects their evaluation and selection of problems at the early stage of research. The study highlights the significance of problems as an important, yet overlooked reflexivity of tourism knowledge production.

\section{GíRiş}

Son yıllarda turizm bilgisinin hizla artması bu bilginin özdüşünümselliği üzerine ${ }^{3}$ olan ilginin artmasını da sağlamıştır. Bu özdüşünümselliğin önemli bir şekli şu önerme ile ortaya konmuştur;

\footnotetext{
“Kun Lai, Jun Li ve Noel Scott (2015). Tourism problemology: Reflexivity of knowledge making. Annals of Tourism Research 51, ss. 17-33. DOI: http://dx.doi.org/10.1016/j.annals.2014.12.003" künyesini taşıyan makaleden dergi yayıncısının izni alınarak çevrilmiştir.

** Sorumlu yazar: Tel.: +86 20 84114584; faks: +86 20 84114569, e-posta: laikun@mail.sysu.edu.cn (K. Lai), lijun36@mail.sysu. edu.cn (J. Li), noel.scott@griffith.edu.au (N. Scott).

Çevirmenin notu: Özdüşünümsellik (dönüşlü düşünce, düşünümsellik, reflexivity, self-reflexivity), en genel anlamı ile
} araştırmacının kavrama yaptığı "öznel yüklemeler" olarak “özellikle turizme yönelik olan dergilerde, kitaplarda ve konferanslardaki gelişmeler apaçık ortada olmasına rağmen genel analitik düzeyde bu gelişmeler, eksik kuramsallaştırılmış, eklektik ve nispetsiz (kuramla benzeşmeyen, kurama uyumsuz) kalmaktadır" (Meethan 2001: 2) ya da "bu tarz bir gelişme (bu tarz çalışmalar) basitçe, daha önce ya-

açıklanabilir (bkz. Karabağ Sarı, Ç. (2014) MomentDergi, 1(1) ss.137-146). Bu görüşe göre toplanan verilerin çoğu, araştırmac1nın süzgecinden geçmekte, onun kendi izlenimleri ve kuramsal yönelimindeki önyargıları bu süzgecin deliklerinin ebatını belirlemektedir. Buna göre, toplumsal ve kültürel dünyanın, araştırmacının "ben'i" olmadan incelenmesi mümkün değildir (bkz. Pala, Ş. (2004). Antropoloji ve Onun Alameti Farikasi: Katılarak Gözlem, Hacettepe Üniversitesi Edebiyat Fakültesi Dergisi, 21 (1): ss.123-141) 
pılmış bir araştırmanın temel olarak doğrulanması ve tekrarlanmasına dayanan daha geniş bir sürümüyle sonuçlanmaktadır" (Ateljevic, Pritchard ve Morgan 2007: 12). Bunun daha yaygın ve örgütlü tezahürü, ancak, turizm bilgisinin kendisini (ör., Xiao, Jafari, Cloke ve Tribe 2013; Xiao ve Smith 2006), tüketimini (ör., Cooper 2006; Xiao ve Smith 2007) ve üretimini (ör., Franklin ve Crang 2001; Hall 2004; Platenkamp ve Botterill 2013) yeniden ele alan araştırmacıların artan ilgisi ile yansıtılabilir. Böyle bir ilgi turizm bilgisine sosyolojik bir yaklaşım da kazandıracaktır.

Turizm bilgisi üretmeye yönelik özdüşünümler bilhassa önemlidir çünkü mantıken bilginin üretimi, bu bilginin kendisinden ve tüketiminden daha önce gelmektedir. Bilgi üretim sürecini paradigmaya bağlılık (ör., Ateljevic vd. 2007; Hall 2004; Phillimore ve Goodson 2004; Platenkamp ve Botterill 2013), araştırma yöntemleri (ör., Ritchie, Burns ve Palmer 2005), disiplin arka planı (ör., Tribe 2004), araştırmacı ağı (ör., Benckendorff ve Zehrer 2013) ve yeni teknolojiler (ör., Liburd 2012) tireler arasindaki bölümü, "gibi"den önceye alabilirmiyiz, gibi çok sayıda faktör etkilemektedir. Mevcut çalışma, turizm bilgisi üretiminde ortaya çıkan - önemli ancak nispeten daha az incelenmiş bir faktör olan - araştırma probleminin rolünü inceleyerek bu özel ilgi alanının takibini devam ettirmektedir. Problemler genel olarak araştırma faaliyetlerinin merkezi olarak kabul edilmiştir. Karl Popper, Thomas Kuhn ve Larry Laudan gibi ünlü bilim felsefecileri problemleri önemli ölçüde vurgulamışlardır.

Araştırmada problemlerin oynadı̆̆ 1 bu önemli rol, bilim felsefesinin yeni yeni ortaya çıkan bir alt dalı olarak "problemolojiyi" ön plana çıkarmıştır (Lin, 1990, 1991, 2005). "Problemoloji" terimi ilk olarak 1987 yılında düzenlenen 8. Uluslararası Bilim Mantığı, Metodolojisi ve Felsefesi Kongresi'nde ortaya atılmıştır (Lin, 2005). Problem araştırması anlamina gelen problemoloji, problemlerin bir bütün olarak felsefi şekilde incelenmesi olarak kabul edilmektedir. İlk olarak felsefeciler tarafından tartışılmış olmasına rağmen, fizik (ör., Einstein ve Infeld 1961), matematik (ör., Hilbert 2009), yapay zeka (ör., Luger 2009) ve psikoloji (ör., Davidson ve Sternberg 2003) alanlarında çalışan araştırmacılarda bu başlığa ilgi göstermişlerdir. Böylelikle problemolojinin yaptığı çağrışımlar 1990'lardan bu yana genişlemiştir. Problemoloji günümüzde, ge- nel anlamda sorunları incelemeye odaklanmış her çeşit çalışmayı ifade etmektedir (Zhang 2005).

Problemolojinin 1980'lerden itibaren kazandiğ ivmelenmeye rağmen, turizm araştırması topluluğu buna pek ilgi göstermemiştir. Turizm araştırmacıları problemlerin genel doğasını anlamak yerine, tekil problemlerin çözümüne daha çok ilgi göstermiştir. Turizm alanyazını, ağırlayan-konuk çatışmaları, cinsiyet eşitsizliği, ikincil konutlar, turizm ile ilgili suçlar, bir kavram olarak turizmin belirsizliği ve turizmin disiplin olup olmadığı üzerine yapılan tartışmalar gibi spesifik sorunları içermektedir. Buna rağmen alanyazında doğrudan doğruya "bu problemlerin doğasının ne olduğunu" ve "bunların turizm bilgisi üretme sürecindeki rollerinin ne olduğunu" sorgulayan çalışmalar bulunmamaktadır. Problemlerin doğasına odaklanmış çalışmaların bulunmaması yanlış değildir; spesifik sorunları çözmeye çabalamak somut turizm bilgisinin üretilmesi açısından vazgeçilmez bir iştir. Ancak, problemler turizm araştırmalarının (diğer tüm bilimsel araştırmalarda olduğu gibi) temelini oluşturmaktadır; bu sebeple problemler hakkında daha fazla şeyin bilinmesi önemlidir. Çözülmesi gerekenin ne olduğuna yönelik oluşturulan özbilinç daha iyi çözümlerin ortaya konulabilmesine katkıda bulunabilir.

$\mathrm{Bu}$ çalışma ile turizm araştırması problemleri sistematik ve derinlemesine bir bütün olarak ele alınarak, yukarıda bahsedilen boşluğu doldurmak amaçlanmaktadır. Diğer bir deyişle bu çalışmada iki aşamalı bir araştırma ile, ilk defa olarak, bir turizm problemolojisi (TP) oluşturulmaya yada turizm için bir problemoloji uygulaması oluşturulmaya çalışılmıştır: ilk aşamada problemoloji yazını temelinde bir model yapısı oluşturulmuş, ikinci aşamada ise model ampirik açıdan tanımlanmış ve test edilmiştir. Bu noktada özellikle birbiri ile ilişkili üç soru ele alınmıştır: (a) Turizm problemlerinin doğası nedir? (b) Turizm problemlerine ne etki eder? ve (c) Turizm sorunlarının etkileri nelerdir? $\mathrm{Bu}$ çalışma ile turizm problemlerine ve turizm bilgisi üretiminin özdüşünümselliğine yönelik olan mevcut anlayış geliştirilebilir.

\section{TURIZM PROBLEMLERININ KURAMSALLAŞTIRILMASI}

Turizm problemolojisi (TP), tümevarım ya da tümdengelim yolu ile gerçekleştirilebilir. Tümevarım 
ile, TP aracılığında ne gibi spesifik turizm problemlerinin çözüldüğü özetlenebilir. Tümdengelim ile ise, mevcut problemoloji yazınından turizm problemolojisi ortaya çıkarılabilir. Bu çalışmada, mantıksal açıdan kullanılabilir ve pratik olarak gerekli bulunduğundan dolayı tümdengelim yaklaşımina başvurulmuştur. TP, problemolojinin turizm alanında somutlaştırılması ile ilgilidir; problemolojinin temel ilkeleri bu sayede TP'ye uygulanabilir. Problemoloji yeni yeni ortaya çlkmakta olan bir alan olsa da (Lin, 2005; Zhang, 2005), TP'nin kuramsal altyapısına hizmet edecek somut bir yazın yapısı oluşturulmuş durumdadır. Hâlihazırda mevcut olan bir yapıdan (ör. problemoloji yazını) yola çıkıldığından ve felsefe ile turizm arasında yapıcı bir dialog kurabildiğinden dolayı tümdengelim yaklaşımı uygulanabilirdir.

Tümdengelim yaklaşımı seçildikten sonra, TP'nin kuramsal altyapısı ortaya konulmuştur. Problemoloji ilk başlarda problemlerin felsefi aç1dan incelenmesini ifade ederken, sonraları ortaya çıkan gelişmelerle birlikte daha geniş bir anlama kavuşmuştur (Lin 2005; Zhang 2005). Problemolojinin üç hiyerarşik düzeyi kapsadığı düşünülebilir. Bunlar; (a) etkili filozoflar tarafından işlenen klasik problem çekirdeği, (b) problemoloji terminolojisini kullanarak hazırlanmış problem odaklı çalışmalardan oluşan ara düzey ve (c) kendi disiplinleri ya da alanlarında faaliyet gösteren bilim insanları tarafından çalışılan problemler üzerindeki tartışmaları içeren çeperdir. Problemolojinin bu farklı düzeylerinin nasıl bir ilişki içerisinde olduğu ve birleşik bir sistemi nasıl oluşturdukları ise kendi başına önem arz eden bir sorudur. Ancak bu endişeler mevcut çalışmanın kapsamı dışındadır. TP'nin yapısı içerisinde bahsi geçen tüm bu düzeyler bulunmaktadır fakat bu çalışmada çekirdek düzeyine daha fazla ağırlık verilmiştir.

Eleştirel yazın taraması, problemolojinin üç temel bileşenden oluşan karmaşık bir içeriğe ve yapıya sahip olduğunu ortaya koymuştur. Bunlar; problemlerin doğası, problemlerin öncülleri ve problemlerin sonuçlarıdır. İlk bileşen problemlerin ne olduğu ile ilgilenmektedir. Problemlerin birden çok anlamı vardır ve gerçekte bunlar kesin tanımların gözden kaçmasına yol açmaktadır (Lin 2005; Zhang 2005). Mantığın tanım kuramı ile s1nanan problemoloji yazını (Copi ve Cohen 2005; Hurley 2008), hem problemlerin çağrıştırdığı anlamları hem de problemler tarafından ifade edilen anlamları ortaya koymuştur. Problemler üzerine yazında yer alan çok sayıda tanımdan altısı dikkate değerdir. Buna göre problemler; (a) araştırmacıların üstesinden gelmesi gereken zorluklar (Collingwood 1948; Dewey 1910; Popper 1972), (b) mevcut koşullar ile arzulanan hedefler arasındaki engeller (Sternberg ve Spear-Swerling 1996), (c) açılama idealleri ile mevcut kabiliyetler (Toulmin 1972) ya da mevcut ve ideal durumlar arasındaki boşluklar (He 1983; Lin 2005; Simon 1981), (d) herhangi bir kuramsal sistemdeki çelişkiler (Laudan 1977; Liu 1987), (e) insanların çözmesi gereken labirentler (Zhang 2005) ve (f) insanlarm bir durumdan ya da gözlemden türettikleri bulmacalar (Laudan 1977; Lin 2005) olarak tanımlanmıştır.

Problemlerin ifade edilmesine ilişkin çok sayıda siniflandırma bulunmaktadır. Bu hakiki ve sahte, gerçek ve potansiyel, kontrol edilebilen ve edilemeyen, normal ve anormal, kavramsal ve ampirik, çözülmüş ve çözülmemiş, pratik ve kuramsal, açık ve kapalı, felsefi ve bilimsel gibi sınıflandırmalardır. Bunlar arasından Laudan (1977) tarafından yapılan kavramsal ve ampirik sınıflandırma diğerlerine nazaran daha kullanışlı görünmektedir. Ampirik problem "doğal dünya ile ilgili bize garip gelen ya da diğer bir değişle açıklamaya ihtiyaç duyan herşey" (s. 15) iken; kavramsal problem, bir kuram "bazı içsel tutarsızlıklar sergilediğinde... [ya da] başka bir kuram ile çatıştığında" ortaya çıkar (p. 49). Bugüne kadar problemlerin anlamı ve sinıflandırılması üzerine evremsel bir uzlaşıya henüz ulaşılmamıştır.

Problemolojinin ikinci bileşeni, problemleri ortaya çıkaran çok sayıda faktörü içermektedir. Bu faktörler, kişisel ve çevresel olarak iki grupta ele alınabilirler (Zhang 2005: 293-296). Kişisel faktörler, araştırma tecrübesi (Popper 2001), paradigmaya bağlılık (Kuhn 1962), dünya görüşü (Patterson ve Williams 1998), bilgiye yönelik ilgi (Habermas 1978), araştırmacının bilgi altyapısı -arkaplan bilgisi- (Popper 1959; Laudan 1977), araştırmacının öznel -subjektif- durumu (ör. varsayım, şüphe, imgelem -hayal gücü-) (Einstein ve Infeld 1961) ve felsefi bakış açısı (Rosenberg 2008) gibi parçalardan oluşurken, çevresel faktörler araştırma topluluğunu (Kuhn 1962), araştırma geleneğini (Laudan 1977), tarihsel bağlamı (Collingwood 1948), kültürel bağlamı (Lyotard, 1984), problem durumunu (Sternberg ve Spear-Swerling 1996), bilimsel bilgiye 
ve bilgi üretim şekline yönelik kamusal beklentiyi içerir (Gibbons 1994; Nowotny, Scott ve Gibbons 2001). Bu faktörler problemin tanımlanmasını, ortaya konmasını, değerlendirilmesini, seçilmesini ve çözülmesini etkileyebilirler. Yukarıda bahsedilen listeler detaylı olmamasına rağmen, kişisel-çevresel model bu faktörlerin ve aralarındaki karmaşık ilişkilerin anlaşılması için faydalıdır.

Problemolojinin üçüncü bileşeni ise problemlerin değeri üzerine odaklanmıştır. Problemlerin genel etkileri farklı bağlamlar içinde ele alınmıştır. Bu noktada Zhang (2005: 1)'in bahsettiği anektod bu durumu anlatmaktadır: Bertrand Russell bir keresinde Cambridge Üniversitesi'nden felsefeci George Moore'a en iyi öğrencisinin kim olduğunu sormuştur. Moore'un buna cevabı derslerinde kendisine çok sayıda soru yönelten (problemlerin dışa vurumu) "Ludwig Wittgenstein" olmuştur. Yıllar sonra Wittgenstein gerçekten de Russell'dan daha fazla ün sahibi oldu. Bunun nedeni sorulduğunda, Moore'un cevabı; "Russell'in sonraki kariyerinde çözeceği fazla bir problemi yoktu." olmuştur. Bu örnekte görüldüğü, felsefeciler motive olmak ve çalışmak için problemlere ihtiyaç duyarlar. Öyleki felsefeciler yaygın olarak Çin'in Problemi (Russell 1922), Insanin Problemleri (Dewey 1965), Hayat Problem Çözmektir (Popper 1999) gibi kitaplarında problemlerin bu genel önemini vurgulamışlardır.

Yaygın şekilde atfedilen bu önemden ayrı olarak, problemlerin araştırmalar üzerinde doğrudan ve daha belirgin etkileri vardır. Problemler, araştırma faaliyetlerini başlatmanın, yönetmenin ve değerlendirmenin esasıdır. Bu fikir, ya da belirli bazı parçaları, Dewey'in (1910) beş aşamalı araştırma methodolojisinde, Popper'in (1959) bilimsel araştırmanın mantığında, Laudan'ın (1977) bilimsel ilerleme modelinde, Lakatos'un (1978) araştırma programı kavramında bulunabilir. Popper'ın (1972: 164) ünlü araştırma modeli. P1-GK-HAP2 bu fikir için için iyi bir açılamadır.

P1 başlangıç problemidir. GK ("geçici kuram") ise ilk olarak ulaştığımız imgesel varsayımsal çözümdür (ör. ilk geçici yorumumuz). HA ("hata ayıklama") ise varsayımımız, geçici yorumumuz üzerinde yapılan ciddi bir eleştirel incelemeden ibarettir... P2, problemlerimizin çözümü için yaptığımız ilk ciddi girişimin sonucunda ortaya çıan problem vaziyetidir. Bu bizi ikinci (ve da-

4 Çevirmenin notu: Geçici kuram (tentative theory), test edilmek üzere önerilmiş olan kuramdır. ha çok) denemeyi yapmaya itecektir. Eğer yorum -hipotez- ...yeni problemlere yeni bir ışık tutabilirse... ya da eğer... kimileri başlangıç olarak görülmemiş bir çok alt problemi açıklayabilirse... tatmin edici bir anlayışa ulaşılabilecektir. Böylece, P1'i daha sonraları karşılaştığımız problemler (Pn) ile karşılaştırarak yaptığımız ilerlemeyi ölçebileceğimiz söylenebilir.

$\mathrm{Bu}$ atfın temelindeki fikir, herhangi bir bilimsel araştırmanın problem çözme etkinlikleri ile güdülendiği, bu etkinlikler tarafından yönlendirildiği ve bu etkinlikler aracıllı̆ıyla değerlendirildiğidir. Bilim, problemlerin genel ve özel etkilerini kendi başlarına önemli araştırma konuları haline getirmektir (Lin 2005; Zhang 2005).

Problemolojinin temel kavramları (ör. problemin doğası, problemin öncülü ve problemin sonucu) ortaya konulduktan sonra TP oluşturulmuştur. Bu çalışmada tümdengelim mantığı temelinde TP; turizm araştırması problemlerinin doğasını, öncüllerini ve sonuçlarını bir bütün olarak kendine özgü şekilde, sistematik ve derinlemesine inceleyen bir çalışma alanı olarak tanımlamıştır. Problemoloji gibi TP de üç parçadan oluşmaktadır: (1) turizm probleminin doğası (TPD), turizm probleminin öncülleri (TPÖ) ve turizm probleminin sonuçları (TPS). Bu parçalar, iki tip etkinin birarada olduğu, içiçe geçmiş bir yapı içerisinde bulunmaktadır: temel etki olarak TPÖ $\rightarrow$ TPD $\rightarrow$ TPS; küçük etkiler olarak TPD $\rightarrow$ TPÖ, TPS $\rightarrow$ TPD/TPÖ ve ТPÖ $\rightarrow$ TPS (Şekil 1).

$\mathrm{Bu}$ yapılar ve yapıların birbirleri ile ilişkileri problemoloji yazını ve model kuramlarının incelenmesi tarafından belirlenir (Giere, 2004; Hodges, 1993). Model, yapıları üç aşamadan oluşmaktadır: (a) ilk aşamadaki TPD, TPÖ ve TPS; (b) ikinci aşamadaki kişisel ve çevresel TPÖ'leri, birincil ve ikincil TPD'ler, özel ve genel TPS'ler; ve (c) üçüncü aşamada (b)'ye ait yapilar.

(a) ve (b)'deki yapılar doğrudan doğruya problemoloji yazınından çıkartılmıştır. (c)'deki yapılar ise problemoloji yazını ile yazarların deneyimlerinin bir sentezinden oluşmaktadır. Kişisel TPÖ, araştırma amacı, paradigmaya bağlılık, araştırma deneyimi ve araştırmacının demografik özellikleri olarak dört boyut altında sınıflandırılmıştır. Çevresel TPÖ, nesnel durum ve öznel algı olmak üzere ikiye bölünmüştür. TPS, problemlerin araştırmanın erken, orta ve sonuç aşamalarındaki etkilerini temsil edecek üç alt boyut şeklinde düzenlenmiştir. 
Turizm Problemolojisi: Bilgi Üretmenin Özdüşünümselliği / Tourism Problemology: Reflexivity Of Knowledge Making

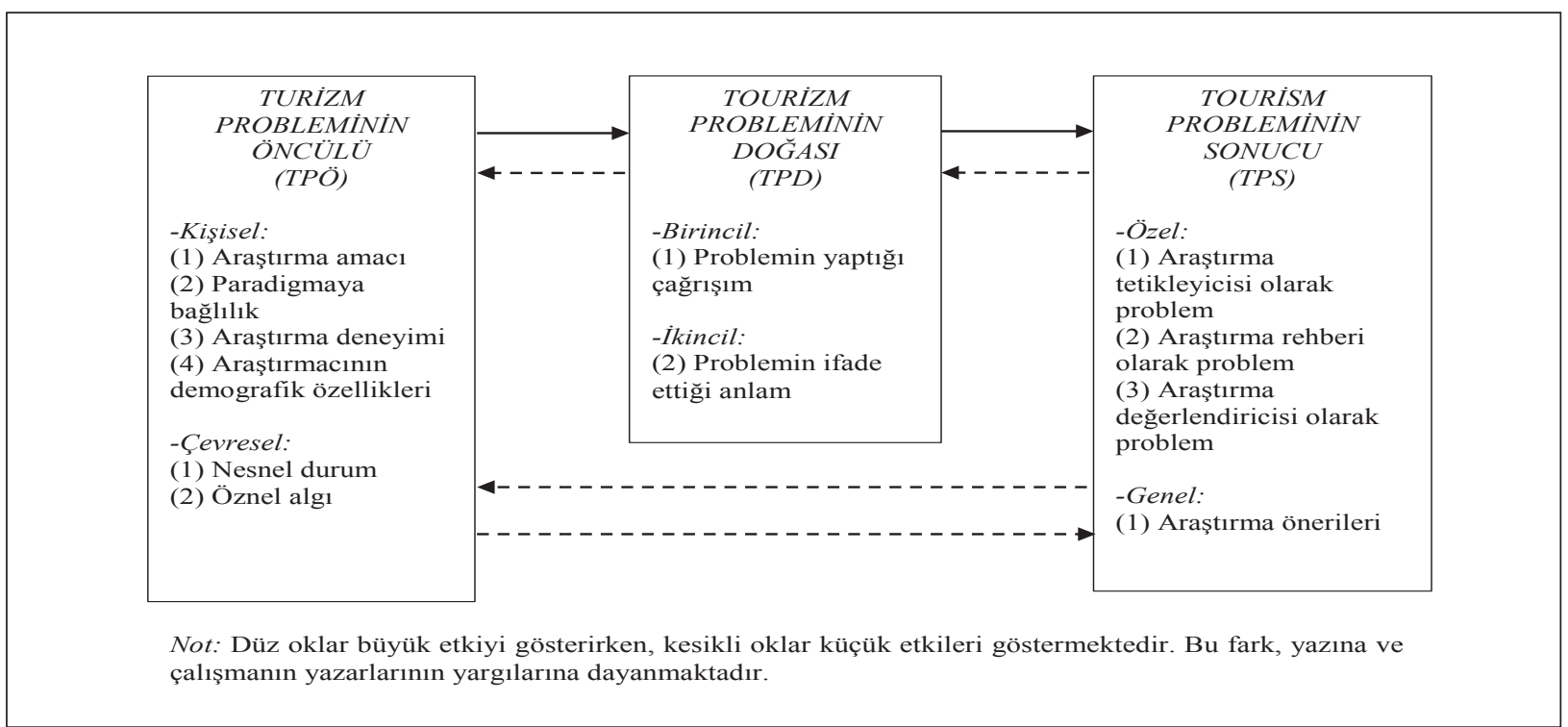

Şekil 1. Turizm Problemolojisi (TP) Kuramsal Modeli

Bu boyutlar, araştırma tetikleyicisi olarak problem, araştırma rehberi olarak problem ve araştırma değerlendiricisi olarak problemdir. Yapilar arasındaki ana ilişkiler, problemoloji yazınında TPÖ, TPN ve TPS arasındaki doğal mantık temelinde ele alınmıştır. Sosyal bilimlerde yapılar arasındaki ilişkiler ikili ve dinamik (Neuman, 2006) olma eğiliminde olduğundan dolayı küçük etkiler de ele alınmıştır. Bu etkiler modeli daha gerçekçi hale getirmek için ilave edilmiştir.

\section{ARAŞTIRMA YÖNTEMI}

Önemli özellikler: Kuramsal model oluşturduktan sonraki aşama, modelin amprik olarak test edilmesidir. TP modeli Çin'de faaliyet gösteren turizm araştırmacılarından anket yoluyla toplanan veriler üzerinden test edilmiştir. Ampirik testin üç önemli özelliği bulunmaktadır. Bu özelliklerin ilki, modelin test edilmesinin ve belirlenmesinin eş zamanlı olarak gerçekleştirilmiş olmasıdır. Geleneksel olarak, test edilecek modelin tamamen belirlenmiş olması yani gerçeği ne ölçüde temsil ettiğinin bilinmesi gerekmektedir (Giere, 2004; Hodges, 1993). Hâlbuki TP modeli henüz tamamen belirlenmemiştir. Modelin üçüncü düzeyinde yer alan çok yönlü yapıların (ve bu yapıların kendi alt boyutlarının) belirlenmesi gerekmektedir. Bu belirleme işlemi ise gerçek bir ölçüme tabi tutulmadan başar1lamaz.
İkinci özellik ise, testin, yapılar arasındaki özel ilişkilerin belirlenmesi amacı ile üçüncü düzeydeki yapılara uygulanmış olmasıdır. Birinci ve ikinci düzeydeki ilişkilere, teste dayalı sonuçlardan ulaşılmıştır. Üçüncü düzeye ait dört yapı (ör. ikincil TPD, genel TPS, araştırma rehberi olarak problem ve araştırma değerlendiricisi olarak problem), modeldeki diğer üçüncü düzey yapıların karmaşıklığı ve veri toplamanın olanaklılığı açısından çalışma dışında bırakılmıştır. Çünkü tüm yapıları birleştirerek oluşturulacak bir veri toplama aracı (anket) gereksiz şekilde uzun olacaktır. Bu kısıtlamalar göz önüne alındığında, testin, modelin anahtar yapılarının temel etkilerini kapsadığı görülmektedir.

Üçüncü özellik ise, modelin karmaşık doğası gereği ortaya çıkan, veriler arasındaki doğrusal olmayan ve belirsiz ilişkiler, geleneksel model testini gerçekleştirmeyi engellemiştir (ör. modelleri, belirli hipotezlere çevirerek test etmek). Buna alternatif olarak açık uçlu sorular test hipotezleri yerine kullanılmıştır (bilgi için, Cooley ve Lewkowicz 2003): (a) Bir problemin çağrıştırdığı şey nedir? (b) Kişisel TPÖ’leri (ör. araştırma amacı, paradigmaya bağlılık, araştırma deneyimi ve araştırmacının demografik özellikleri) ve çevresel TPÖ'leri (ör. nesnel durum ve öznel algı) problemin yaptığı çağrışımı nasıl etkilerler? ve (c) Araştırma tetikleyicisi olarak problemin yaptığı çağrışımın, problemin üzerindeki etkisi nedir? 
Veri toplama arac1: Veri toplamak amacı ile yarı yapılandırılmış anket kullanılmıştır. Anket ile üçüncü düzeye dâhil olan sekiz yapı grubunun ölçülmesi amaçlanmıştır. Yazarların, veri toplama aracı olarak kalitesini meslektaşlarının önerileri ve işbirlikleri ile oluşturduğu nihai anket dört bölümden oluşmaktadır (Tablo 1). I. Bölüm, TPD'nin göstergeleri arasından görece direkt olan problemin yaptığı çağrışımı ölçmek için kullanılmıştır. Bu yapıyı ölçmek için iki madde kullanılmıştır: [a] altı problem tanımını içeren, yedi seçenekten oluşan çoktan seçmeli bir soru (problemoloji yazınından çıkartılmış altı soru; $1=$ turizmdeki çelişkiler, $2=$ turizm fenomeni içindeki bulmacalar, $3=$ ideal/normal ve mevcut/anormal turizm koşullarının arasındaki boşluklar, 4= turizm fenomeni labirenti, 5= turizm gelişmesinin önündeki engeller ve $6=$ turizm araştırmacilarmin baş etmeleri gereken zorluklar ve alternatif olarak $7=d i-$ $\breve{g}$ er) ve [b] alternatif seçenek olan diğer seçildiğinde cevaplanması için koyulan bir açık uçlu soru (Peki, turizm problemleri üzerine sizin tanımınız nedir?).

II. bölüm ile kişisel TPD'nin dört alt boyutunu ölçmek amaçlanmıştır. Araştırma amacı, Habermas'ın (1987) “insanın ilgisi ya da bilgide aksiyolojik ${ }^{5}$ inanç"da yapmış olduğu teknik, pratik ve özgür bırakan, sinıflandırması temel alınarak, bir soru ile ölçülmüştür. Bu soru beş seçeneğe sahip bir çoktan seçmeli sorudur: $1=$ [turizm araştırmasının amaçları] turizm fenomenini kontrol etmek ve olasılıkları tahmin etmek amacı ile turizmin düzeni$n i^{6}$ bulmak (güçlü teknik amaç), 2= turizm fenomenini kontrol etmek ve bir ölçüde olasilikları tahmin etmek için açıklamalar getirmek (zayıf teknik amaç), 3= olumlu değişiklikler yapabilmek için turizmin gerçeklerini kritisize etmek (özgür bırakan amaç), $4=$ etkileyebilmek amacı ile turizm fenomenini anlamak (pratik amaç), ve $5=b u$ sayılanların hepsi olabilir (içiçe geçmiş amaç). İkinci ve beşinci seçenekler, araştırmanın amacının içiçe geçtiği durumları yansıtmak üzere eklenmiştir.

\footnotetext{
${ }^{5}$ Çevirmenin notu: Aksiyoloji (değerbilgisi, değer öğretisi), değerler üzerine çalışan, değerlerin doğasını, ne türden şeylerin kendi içinde "değer" taşıdığını bir sıradüzen içinde ele alarak, etik, din ve estetiği de göz önünde tutarak inceleyen felsefe dal1dır (Kavram ile ilgili bkz. Güçlü, Uzun, Uzun ve Yolsal. (2003). Felsefe Sözlüğü. Ankara: Bilim ve Sanat).

${ }^{6}$ Çevirmenin notu: Burada yazarlar turizm olayının iç işleyişini kontrol eden dinamiklerin ortaya koyduğu ilişkiler bütününü ifade etmek için "düzen" terimini kullanmışlardır. Ör. Dünya'nın düzeni.
}

Paradigma bağlılığı üç madde ile ölçülmüştür: (a) ontolojik ${ }^{7}$ inanış (çoktan seçmeli: 1= turizm fenomeni bizim dışımızda gerçekleşmektedir ve tarafımızdan tamamen bilinebilir [naif gerçekçiliks]; $2=$ turizm fenomeni bizim dışımızda gerçekleşmektedir fakat tarafımızdan ancak kısmen bilinebilir [gerçekçilik ${ }^{9}$ ]; $3=$ turizm fenomeni gerçektir ve bu gerçek, tarih, iktisat, etik, cinsiyet $v b$. tarafindan birarada belirlenir [tarihsel gerçekçilik ${ }^{10}$ ]; $4=$ gerçek turizm fenomeni yoktur, bunların hepsi öznel olarak inşa edilmiştir [öznelcilik ${ }^{11}$; ve $5=$ bunlarm hepsi olabilir [görecelik ${ }^{12}$ ]: (b) epistemolojik ${ }^{13}$ inanış (çoktan seçmeli: $1=$ araştırmacı ve konu kesinlikle ayrı tutulmalıdır [nötralizm]; 2= araştırmacı ve konu ayrı tutulmalıdır [revize nötralizm]; $3=$ araştırmacı ve konu etkileşim içinde olmalıdır [etkileşimcilik]; 4= araştırmacı ve konu içiçe geçmelidir [öznelerarasılık]; ve $5=$ bunların hepsi olabilir [görecilik]: (c) metodolojik inanış (çoktan seçmeli: $1=$ [turizm araştırması $]$ kesinlikle nicel olmalıdır; $2=$ öncelikle nicel olmalıdır; $3=$ öncelikle nitel olmalıdır; $4=$ kesinlikle nitel olmalıdır; ve $5=$ bunlarm hepsi olabilir). Madde değerleri paradigma yazınından elde edilmiştir (Guba 1990; Guba ve Lincoln 2005; Patterson ve Williams 2005).

\footnotetext{
7 Çevirmenin notu: Ontoloji (varlıkbilgisi), varoluşun doğası ile gerçekliğin varlıksal yapısını soruşturan varlık bilimi, varlık felsefesidir (Kavram ile ilgili bkz. Güçlü vd. a.g.e., 2003).

${ }^{8}$ Çevirmenin notu: Naif gerçekçilik (naive realism), dünyada var olan şeylerin, belirsizlikler ve kuşkular dikkate alınmaksızın, doğrudan doğruya anlanabileceğini savunan öğretidir.

9 Çevirmenin notu: Gerçekçilik (realizm) en genel anlamı ile nesneleri, her ne kadar aykırı görünselerde, olayları da aynı şekilde oldukları gibi içtenlikle kabul etme tutumudur (Kavram ile ilgili bkz. Güçlü vd. a.g.e., 2003).

10 Çevirmenin notu: Tarihsel gerçekçilik (historical realism), görünümlerin kökenine inilmesi ve ontolojik temellerinin sorgulanması, tarihsel gelişiminin ortaya konması ve gelecekte sergileyeceği mümkün gelişim eğrilerine dair bazı esnek çıkarımlarda bulunulmasını esas alan öğretidir (Kavram ile ilgili bkz. Göçmen, D. ve Kaya, G. (2013). Adam Smith'in Siyaset Felsefesine Dair Bir Kuramsal Çerçeve. FLSF 15, ss85-109).

11 Çevirmenin notu: Öznelcilik (sübjektivizm), nesne ile nesnel olana karşı, her koşulda özne ile özneyle ilgili olanı temele koyarak değerlendirme tutumu; bütün değer yargılarının kişinin öznelliğine indirgenerek anlaşılması yaklaşımıdır (Kavram ile ilgili bkz. Güçlü vd. a.g.e., 2003).

12 Çevirmenin notu: Görecilik, diğer adı ile relativizm, en genel anlamını Protagoras'ın "Her şeyin ölçüsü insandır" anlayışında bulan, bütün bilgi ve değerlerin göreli olduğunu ileri süren öğretidir (Kavram ile ilgili bkz. Güçlü vd. a.g.e., 2003).

${ }^{13}$ Çevirmenin notu: Epistemoloji (bilgikuramı, bilgibilim, bilgi felsefesi, bilgi öğretisi), bilimlerin ortaya koydukları felsefi sorunları inceleyen, tek tek bu bilimlerin yöntemlerini, ilkelerini, varsayımlarını ve sonuçlarını eleştirel bir gözle soruşturan
} felsefe dalıdır (Kavram ile ilgili bkz. Güçlü vd. a.g.e., 2003).

Cilt 26 
Araştırma tecrübesi beş madde ile ölçülmüştür: kaç yıldır turizm araştırması ile uğraşıyorsunuz (boşluk doldurma), yayın özelliği (çoktan seçmeli: $1=$ uluslararası düzeyde önemli, $2=$ uluslararası, $3=$ yerel düzeyde önemli, $4=$ yerel, ve $5=$ diğer ya da yayınım yok), yazına hakimiyet (5'li Likert ölçeği, $1=$ çok dü̧̈ük, $5=$ çok yüksek), katılınan konferans sayısı (boşluk doldurma), ve yüklendiği araştırma projesi sayısı (boşluk doldurma). Araştırmacıların demografik özelliklerini ölçmek üzere yaş (boşluk doldurma), cinsiyet (çoktan seçmeli, $1=$ erkek ve $2=$ kadın), eğitim (çoktan seçmeli: 1= doktora, 2= yüksek lisans, $3=$ lisans, ve $4=$ diğer ), akademik durum (çoktan seçmeli: $1=$ turizm profesyoneli ve $2=$ turizm mezunu), ve akademik uzmanlık (boşluk doldurma).

Üçüncü bölümde çevresel TPÖ’nün alt boyutlarının ölçülmesi amaçlanmıştır. Nesnel durum (araştırma çevresinin), iki madde ile ölçülmüştür: çalışılan kurumun yeri (Çin'deki 33 il/eyalet arasinda çoktan seçmeli) ve kurum çeşidi (çoktan seçmeli: 1= uluslararası tanınırlı̆̆ı olan Çin üniversiteleri [bu üniversiteler "985"ler olarak anılmaktadır], 2= yerel tanınırlı̆̆ı olan üniversiteler [bu üniversiteler “985"ler dişlanarak "211"ler olarak anılmaktadır], $3=$ stradan üniversiteler, $4=k o l e j / y \ddot{u} k s e k o k u l$, ve $5=d i$ ğer). "985" ve "211" üniversitelerinin Çin hükümetinin güttügü ve hükümet yatırımları yoluyla dünyaca ünlü araştırma odaklı üniversiteler oluşturma politikaları sonucu ortaya çıktıkları not edilmeli- dir. Hükümet 1995 yılında 112 üniversiteyi "211" üniversiteleri olarak belirlenmiştir. Bu listede yer alan en iyi 39 üniversite ise 1998 yılında "985" üniversiteleri olarak seçilmiştir.

Araştırma çevresine dair öznel algı mikro, mezo ve makro düzeylerde ölçülmüştür. Mikro çevre alg1sı katılımcıların çalıştıkları bölüm/okulların beş boyutta değerlendirilmesi ile ölçülmüştür: ortalama araştırma atmosferi, araştırma çıktısı için talebin katılığı, araştırma rekabeti, araştırma koşullarının uygunluğu, araştırma kaynaklarının ulaşılabilirliğgi (5'li Likert ölçeği, $1=$ çok düşük, 5= çok yüksek). Mezo çevre algısı araştırmacıların çalıştıkları kurumları beş boyut altında değerlendirmesi ile ölçülmüştür: gevşek-katı, kaotik-organize, faydac1l- faydacıl olmayan, işbirlikçi-işbirlikçi olmayan, araştırmayı engelleyen-araştırmaya teşvik eden (7'li semantik farklılıklar ölçeği). Makro çevre algısı ise Çin'in akademik ortamını, mezo düzeyde kullanılan beş madde ile ölçülmüştür.

IV. bölümde, TPS'nin odağı olan araştırma tetikleyicisi olarak problem, problem önerisi, değerlendirmesi ve seçimi boyutları altında ölçülmüştür. Problem önerisi bir madde ile ölçülmüştür: Lütfen, çözülmesi önemli olan üç adet turizm problemi öneriniz. Problem değerlendirme, Çin Ulusal Turizm İdaresi tarafından turizm araştırma projesi olarak önerilen (2007-2011) ve yazarlar tarafından genel turizm yazınından derlenen 20 madde (prob-

Tablo 1. Ölçüm Araçları

\begin{tabular}{|c|c|c|c|}
\hline Veri Kategorisi & Ölçülen Değişkenler & Madde Sayısı & Ölçek Tipi \\
\hline TPD (Birincil) & Problemin yaptığı çağrışım & 2 & $\begin{array}{l}\text { Çoktan seçmeli } \\
\text { Açık uçlu soru }\end{array}$ \\
\hline \multirow[t]{6}{*}{ TPÖ (Kişisel) } & Araştırmanın amacı & 1 & Çoktan seçmeli \\
\hline & Paradigmaya bağlıık & 3 & Çoktan seçmeli \\
\hline & Araştırma deneyimi & 5 & Boşluk doldurma \\
\hline & & & Çoklu seçmeli \\
\hline & & & 5'li Likert \\
\hline & Araşırmacının demografik özellikleri & 5 & $\begin{array}{l}\text { Boşluk doldurma } \\
\text { Çoktan seçmeli }\end{array}$ \\
\hline \multirow[t]{4}{*}{ TPÖ (Çevresel) } & Nesnel durum & 2 & Çoktan seçmeli \\
\hline & Öznel algı (mikro) & 5 & 7’li Likert \\
\hline & Öznel algı (mezo) & 5 & 7’li Semantik farklılıklar \\
\hline & Öznel algı (makro) & 5 & 7’li Semantik farklılıklar \\
\hline \multirow[t]{3}{*}{ TPS (Araştırma tetikleyici olarak problem) } & Problem önerisi & 1 & Açık uçlu soru \\
\hline & Problem değerlendirmesi & 20 & 5’li Likert \\
\hline & Problem seçimi & 1 & Açık uçlu soru \\
\hline
\end{tabular}

Not: TPD (Turizm probleminin doğası), TPÖ (Turizm probleminin öncülü), TPS (Turizm probleminin sonucu). 
lem) ile ölçülmüştür (5'li Likert ölçeği, $1=$ hiç önemli değil, $5=$ çok önemli). Bu problemler, Tribe'ın (2009) turizm soruları sınıflandırması (gerçeklik-, erdemve estetik-yönelimi) temel alınarak üç gruba ayrılmıştır: gerçeklik, erdem, estetik. Problem seçimi ise bir madde ile ölçülmüştür: Bu 20 turizm problemi arasından hangi üçünü, araştırma konusu olarak seçersiniz?

Veri toplama ve araştırmacıların demografik özellikleri. Anket, Çin anakarasında faaliyet gösteren turizm araştırmacılarına dağıtılmıştır. Uluslararası turizm topluluğuna dâhil olan Çin'li araştırmacılar çalışmaya katılmamış olmasına rağmen, bu örneklem doğru bir örneklemdir. Katılımcılar, turizm profesyonelleri ve turizm mezunları olarak iki ana grupta toplanmıştır. Birinci grupta, rassal olarak seçilmiş 40 adet turizm eğitim kurumundan 396 tane profesyonel araştırmacı ve 2010 Lisansüstü Turizm Eğitimi Fuarına katılmış olan 34 Çinli turizm uzmanı bulunmaktadır. İkinci grupta ise Çin'in önde gelen turizm okullarında yüksek lisans eğitimi alan 31 kişi ve 2011 Lisansüstü Turizm Araştırmaları Forumu'na katılmış 25 doktora adayı bulunmaktadır. Katılımcılar Çin'in farklı bölgelerinden dâhil olduklarından dolayı, Çin lisansüstü öğrencilerini temsil edecek uygunlukta bir örneklemdir. Katılımcıların e-posta adresleri, çalıştıkları kurumlardan, fuar ve forum listelerinden elde edilmiştir.

Lisansüstü eğitim alan ve turizm uzmanı olan katılımcılar amaca yönelik olarak, kotalı ve tabaka- l1 rassal örnekleme yöntemleri bir arada kullanılarak seçilmişlerdir. 2012 yılı verilerine göre Çin'de 436 kurum lisans düzeyinde turizm işletmeciliği eğitimi vermektedir: "985"lerden ( $\mathrm{n}=20)$, " 211 "lerden $(n=41)$, siradan üniversitelerden $(n=123)$ ve kamu/özel kolej/yüksekokul'lardan ( $\mathrm{n}=252)$. Her dört kategori için 10 üniversite rassal olarak seçilmiştir; ilk iki kategoriye, araştırma odaklı olduklarından dolayı öncelik tanınmıştır. Seçilen araştırmacıların e-posta adresleri, çalıştıkları kurumların resmi internet adreslerinden alınmıştır. İnternet sayfası olmayan ya da sayfasında araştırmacılarının e-posta adresleri bulunmayan üniversitelerin yerine, aynı bölgede faaliyet gösteren benzer dereceye sahip üniversiteler kullanılmıştır. Seçilen kurumlara bağlı olarak faaliyet göstermesine rağmen, herhangi bir nedenden e-posta adresi kullanılmayan araştırmacılar, çalışma dışında bırakılmışlardır.

Hedef araştırmacılarla, ticari bir çevrimiçi anket sağlayıcısı aracılığı ile üç-aşamalı anket için iletişime geçilmiştir. İlk aşamada (Aralık 2011), anket davetinin yer aldığı e-postalar 486 araştırmacıya gönderilmiştir; bunun sonucunda 92 geçerli dönüş sağlanmıştır. İkinci aşamada (Ocak 2012), dönüş alınamayan araştırmacılara tekrar e-posta atılmıştır. Bunun sonucunda 84 adet dönüş daha sağlanmıştır. Üçüncü aşamada (Mayıs 2012), 36 ek dönüş daha sağlanmıştır. Bu üç aşama sonunda toplam

${ }^{14}$ Correspondence analysis.

Tablo 2. Problemin Yaptığı Çağrışımı Tahmin Etme Özelliğine Sahip TPÖ’ler

\begin{tabular}{lccccr}
\hline & $\beta$ & Standart hatab & $d f$ & & \\
\hline Bağımsız değişkenler & & & 3 & & \\
\hline Düzen (Üniv.)a & -.583 & .341 & 5 & 2.921 & .036 \\
\hline Düzen (Çin) & -.506 & .316 & 4 & 2.563 & .030 \\
\hline Katııık (Çin) & .445 & .273 & 4 & 2.667 & .035 \\
\hline Epistemolojik inanış & .279 & .107 & 4 & 6.757 & .000 \\
\hline Kurum tipi & .218 & .102 & 4 & 4.514 & .002 \\
\hline Aksiyolojik inanış & .209 & .102 & 4 & 4.148 & .003 \\
\hline Ontolojik inanış & .179 & .097 & 4 & 3.427 & .011 \\
\hline Ölçüm özeti & Düzeltilmiş R2 & $\mathrm{F}$ & $\mathrm{p}$ & & \\
\hline
\end{tabular}

Not: aBu değişken katılımcıların görev yaptıkları kurumun araştırma çevresi hakkındaki algılarını, kaotik-düzenli olup olmadığını ölçmektedir (7'li semantik farklılıklar ölçeği). Aynı durum "Katlık" (Çin) ve "Düzen" (Çin) değişkenleri için de geçerlidir. bBu istatistik, bootstrap tahminine dayanmaktadır (bootstrap örneklemesi= 1000). 

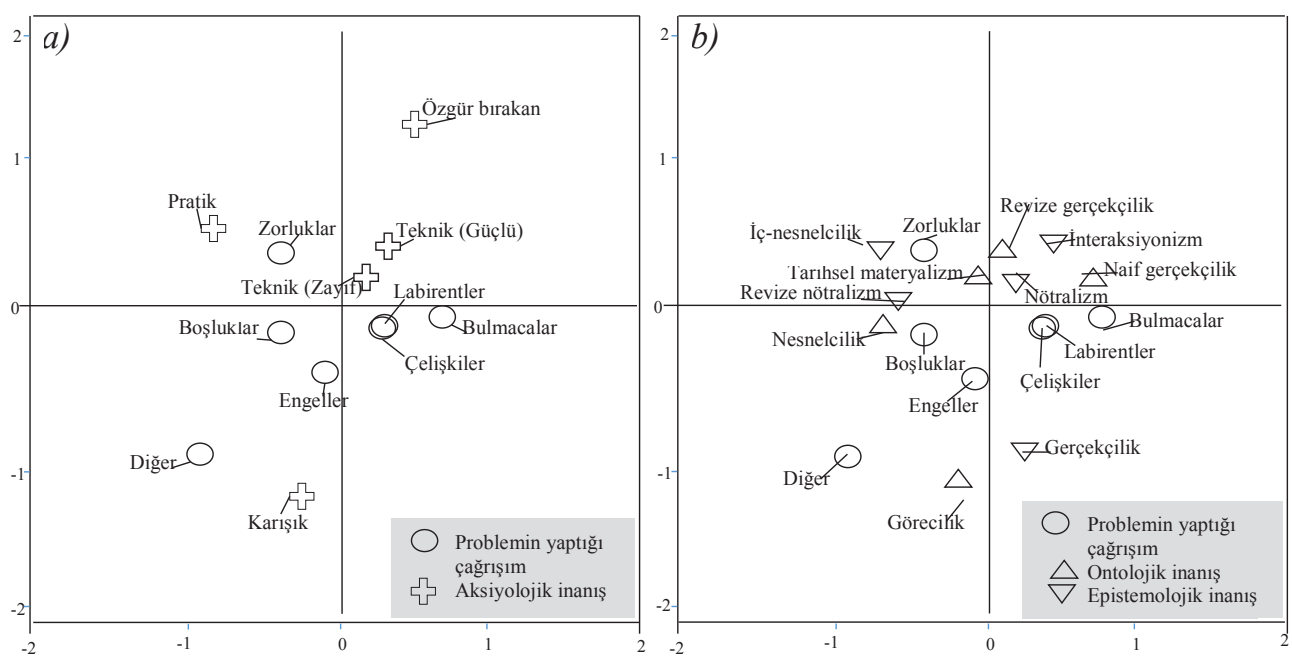

Not: Karşılıklılık analizi, normalize ana bileşenlerle yapılmıştır.

Şekil 2. Kişisel TPÖ'nün, Problemin Yaptığı Çağrışım Üzerindeki Etkileri

212 örnek (\%43,62 dönüş oranı) toplanmıştır. Katılimcilar arasinda turizm profesyonelleri \%73,68 iken, turizm mezunları \%26,32 olarak ortaya çıkmıştır. Cinsiyet dağılımları, \%51,2 erkek ve \%48,8 kadın olmak üzere neredeyse eşit çıkmıştır. Yaş grupları göz önüne alındığında katılımcılar beş grupta toplanmıştır: 21-25 (\%14,6), 26-30 (\%10,4), 31-40 (\%44,8), 41-50 (\%24,5), ve 51-60 (\%5,7). Eğitim durumu göz önüne alındığında katılımcıların $\% 57,4$ 'ünün doktora, \%37,3'ünün yüksek lisans ve \%5,3'ünün lisans derecesine sahip olduğu görülmüştür. Branşlar göz önüne alındığında 17 akademik disiplin üzerinde bir dağılım gözlenmiştir. Bu disiplinler arasında ilk üç \%54,25 ile yönetimorganizasyon, \%23,58 ile coğrafya ve \%5,66 ile iktisat olarak ortaya çıkmıştır. Katılımcılar arasında “985"lerden mezun olanların oran1 \%40,1 iken, “211"lerden \%9,9, siradan üniversitelerden \%44,3, kolej/yüksekokullardan \%2,4 ve diğer kurum türlerinden \%3,3'lük bir mezuniyet oranı ortaya çıkmıştır.

Veri analizi: Veriler öncelikle çok değişkenli analize ve nitel içerik analizine tabi tutulmuşlardır. İstatistiksel açıdan anlamlı ilişkileri saptamak için kategorik regresyon modellemesi kullanılmıştır. Verilerin çoğunluğu süreklilik arz etmemektedir (Tablo 1). Regresyon modeli istatistikleri (ör. b, q ve
R2), istatistiki düzeyleri ve ilişkilerin yoğunluğunu yakalamıştır. Kovaryans değerlerini yorumlayabilmek üzere karşılıklılık analizi ${ }^{14}$ yapılmıştır. Bu yöntem, değişkenlerin değerleri arasındaki ilişkilerin görsel açıdan tespiti için, iki ya da daha fazla değişkenin iki boyutlu bir uzayda gösterilmesine dayanmaktadır. Genel olarak, iki değişkenin değerleri arasında benzer bir rota varsa ve bu değerler aynı boşluğa denk düşüyorlarsa, bu değişkenler birbirleri ile ilişkilidir, ya da diğer bir değişkenle kovaryansa sahiptirler (Hair, Black, Babin, Anderson, \& Tatham, 2010). Ayrıca, problemin yaptığ çağrışımın, problemin değerlendirilmesi üzerindeki etkisini saptamak üzere, 20 test probleminin farklı problem tanım grupları arasında ortaya çıkan anlamlılığının değerlendirilmesi için tek-yönlü ANOVA analizi kullanılmıştır.

\section{ARAŞTIRMA BULGULARI}

Turizm problemlerinin doğası: Turizm problemlerinin tanımlanmasına yönelik katılımcı cevapları geniş bir eksende çeşitlilik göstermektedir. Yedi seçenek arasında en çok tercih edilen seçenek " $t u$ rizm araştırmacılarının baş etmeleri gereken zorluklar $(\% 39,7)$ ” seçeneğidir. Bu seçeneği “turizmdeki çelişkiler $(\% 21,1)$ ", "turizm fenomeni içindeki bulmaca- 

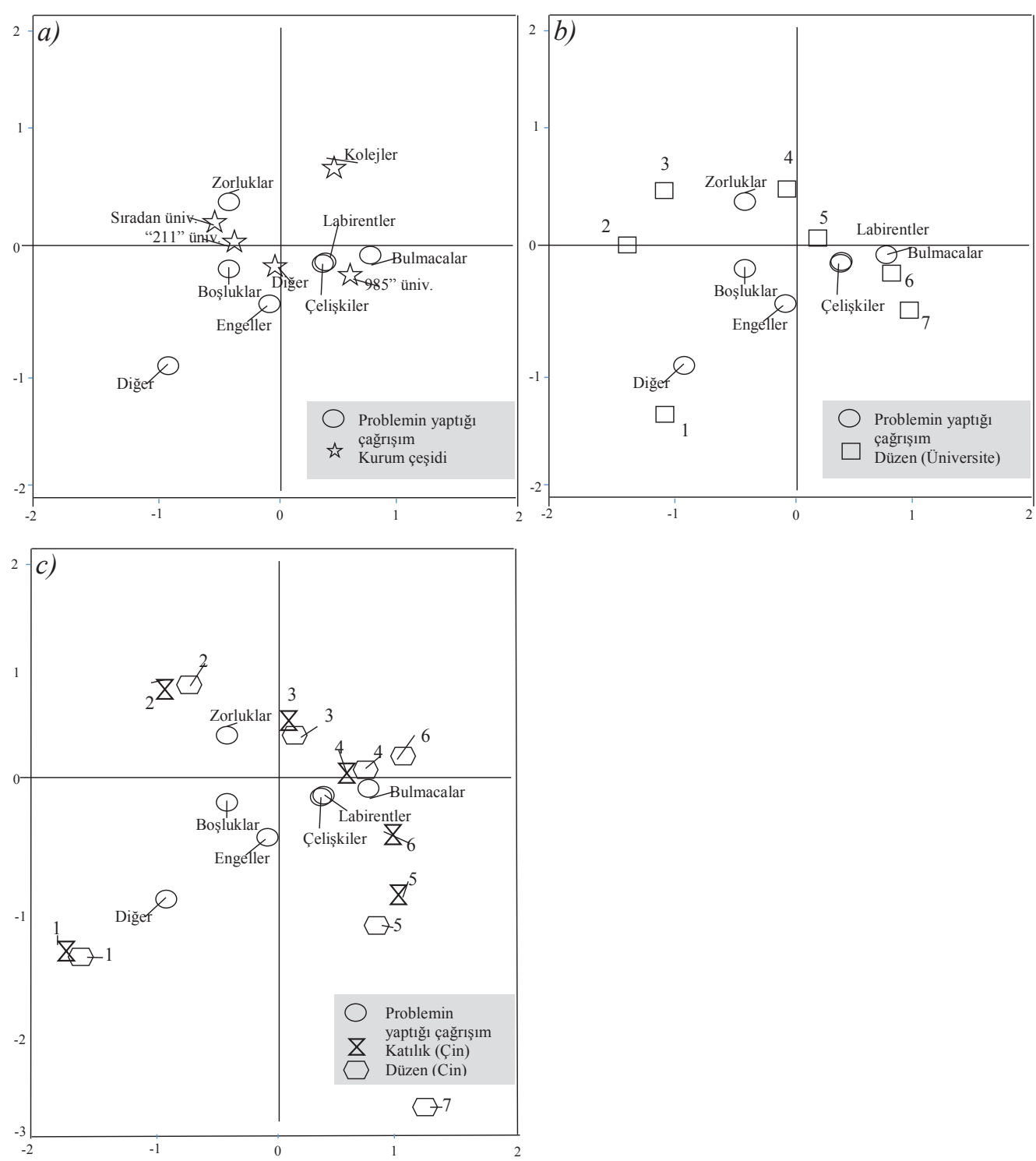

Not: Şekil 3b'de "Düzen (üniv.) 7'li semantik ölçekle ölçülmüştür (1=kaotik, 7=organize). Şekil 3c'de hem" Katılık (Çin)" (1=gevşek, 7=katı), hem de "Düzen (Çin)" (1=kaotik, 7=organize) aynı şekilde ölcülmüstür.

Şekil 3. Çevresel TPÖ’nün, Problemin Yaptığı Çağrışım Üzerindeki Etkileri

lar $(\% 13,4)$, "turizm gelişmesinin önündeki engeller $(\% 9,1)$, "ideal/normal ve mevcut/anormal turizm koşullarının arasındaki boşluklar (\%6,7), "turizm fenomeni labirenti $(\% 6,7)$, ve "diğer $(\% 3,4)$ olarak takip etmektedir. Bu sonuçlar, katılımcıların çoğunun turizm problemlerini uğraşması zor ve çelişkili bulduğunu göstermektedir.
Turizm problemlerinin tanımına yönelik açık uçlu cevaplar ise üç grup altında toplanmıştır. İlk grup turizm problemlerine yönelik açık tanımlamaları içermektedir. Bu tanımlamalar: "gerçeklikten gelen ve kuramsal önemi olan bir problem" (Katılımcı \#81, doçent doktor, kadın, 37); (turizm gelişmesi sürecinde yaygın olarak bulunan bilim- 
sel problemler ve turizm kuramlarının gelişimi içinde bulunan yapısal bilimsel problemler" (Katılımcı \#114, doçent doktor, erkek, 38), ve "turizmin kavramsal sistemleri ve genel düzeni ile ilgili tartışma ve uygulamalar" (Katılımcı \#199, lisansüstü, erkek, 35). İkinci grup ise turizm problemlerini tanımlamanın zorluklarına değinmiştir. Bunlara göre: "[turizm problemini tanımlama] büyük bir projedir ve [turizm problemleri] kolaylıkla açılanamaz" (Katılımcı \#129, profesör, erkek, 58) ve "[turizm problemlerini tanımlamak] zorluklar içerir ve [turizm] ancak kendini adayarak bilinebilir" (Katılımcı \#172 doçent doktor, erkek, 37).

Üçüncü grup ise yöneltilen soru karşısında kafası karışan iki katılımcıdan oluşmaktadır. Katılımcılardan biri, "[Ben] bunu daha önce düşünmemiştim. Ben sadece yukarıda verilmiş tanımların hiç profesyonel olmadığını düşünüyorum. Akademik turizm problemi nedir? Turizm araştırma problemleri, turizm araştırmasının problemlerinden farkl1mıdır? Sorunuz karşısında kafam karıştı (KatılımC1 \#164, profesör, erkek, 52) " şeklinde yanitlamıştır. Anlaşıldığı kadarı ile ikinci ve üçüncü gruplar araştırma aracının (anketin) geçerliliği konusunda şüphe duymaktadırlar. Fakat bu sayının az olması sebebi ile anketin uygun olduğu düşünülmektedir.

Turizm problemlerinin öncülü: Veri analizi sonucu, bir problemin yaptığ 1 çağrışımın hem kişisel hemde çevresel TPÖ'den etkilendiği görülmüştür (Tablo 2). Kişisel TPÖ'nın incelenmesi sonucu, problemim yaptığ 1 çağrışımın araştırmacının aksiyolojik inanışına göre değişim gösterdiği görülmüştür. Şekil 2a'de karşılıklılık analizi sonucu elde edilmiş üç ilişki sunulmuştur. Bu ilişkiler, zorluklar/boşluklar ile pratik ilgi, çelişkiler/bulmacalar/ labiretler ile güçlü teknik/zayıf teknik ilgi ve engeller/diğer ile karışık ilgiler arasındadır. Buna ek olarak, paradigmaya bağllığa ait iki değişken (ör. ontolojik inanış ve epistemolojik inanış) ile problemin yaptığı çağrışım arasındaki ilişkilerde sunulmuştur. Şekil $2 \mathrm{~b}$ ontolojik inanış ile problemin yaptığı çağrışım yani, tarihsel materyalizm ile zorluklar, öznelcilik ile boşluklar, naif gerçekçilik ile çelişkiler/bulmacalar/labirentler ve görecelik ile engeller/ diğer arasındaki ilişkileri vermektedir.

Epistemolojik inanışın problemin yaptığı çağr1şım ile ilişkisi ise, öznelerarasılık/revize nötralizm ile zorluklar, revize nötralizm ile boşluklar, nötralizm/etkileşimcilik ile çelişkiler/bulmacalar/la- birentler, ve görecelik ile engeller üzerinden açıklanmıştır. Bu ilişkiler sonucunda, farklı araştırma amaçlarına ve farklı paradigma bağlllıklarına sahip araştırmacıların, turizm problemlerini farklı şekillerde algıladıkları ortaya çıkmıştır. Diğer iki kişisel TPÖ faktörü olan araştırma deneyimi ve araştırmacının demografik özellikleri ile problemin yaptığı çağrışım arasında ilişki olmadığı görülmüştür.

Çevresel TPÖ'nün, problemin yaptığı çağrışım üzerinde etkisi olduğu saptanmıştır. Şekil 3a'da, kurumlara çeşitlerine ait dört değişkenin, problemin yaptığ $\breve{~ c ̧ a g ̆ r ı s ̧ ı m a ~ a i t ~ d e g ̆ i s ̧ k e n l e r ~ i l e ~ i l i s ̧ k i l e-~}$ ri sunulmuştur: sıradan üniversiteler/"211"ler ile zorluklar, "211"ler ile boşluklar, "985"ler ile çelişkiler/bulmacalar/labirentler ve diğer ile engeller/ diğer.

Katılımcılara göre mikro araştırma çevresi (birim/okul) ile problemin yaptığı çağrışım arasında bir ilişki yoktur. Buna karşın, meso (üniversite) ve makro (ülke) araştırma çevresi, problemin yaptı̆̆ 1 çağrışım ile ilişki içerisindedir.

Mezo düzeyde yer alan beş değişkenden biri olan "organizasyon"un, problemin yaptığ çağrışım üzerinde etkili olduğu saptanmıştır. Şekil 3b'de ilişkiler tanımlanmıştır: görev yaptıkları üniversitenin organizasyonuna nötr-olumsuz olan katılımclar turizm problemlerini "zorluklar" olarak tanımlarken, üniversitelerine karşı pozitif algısı olan katılımcılar turizm problemlerini, çelişkiler/bulmacalar/labirentler olarak tanımlamıştır. Bunun yanı sıra düzen (üniversite), faydacılık (üniversite), işbirliği (üniversite) ve araştırma promosyonu (üniversite) değişkenlerinin, problemin yaptığı çağrışım üzerinde bir etkisi olmadığı bulunmuş̧tur.

Makro düzeyde ise, beş değişkenin ikisi olan katılık (Çin) ve organizasyon (Çin) değişkenlerinin, problemin yaptığı çağrışım ile ilişkisi olduğu saptanmıştır. Özellikle, Çin'in araştırma çevresini "katılık" bağlamında çok gevşek, gevşek yada nötr bulan katılımcilar, turizm problemlerini ankette verilen altı tanımdan farklı şekilde tanımlamışlardır (Şekil 3c). Benzer bir dağılım da organizasyon (Çin) ile problemin yaptığ 1 çağrışımda görülmektedir (Şekil 3d). Faydacılık (Çin), işbirliği (Çin), ve araştırma promosyonu (Çin) değişkenlerinin, problemin yaptığ 1 çağrışım üzerinde bir etkisi olmadığı görülmelidir.

Turizm problemlerinin sonuçları: Analiz sonuç- 
larına göre, problemin yaptığı çağrışım, araştırma tetikleyicisi olarak problem ile ilişkilidir. Problem önerisi, araştırma tetikleyicisi olarak problemden etkilenmemesine rağmen, problemin değerlendirilmesi ve problem seçimi bundan etkilenmektedir. Tablo 3'te, araştırmacıların turizm problemlerinin doğasına yönelik anlayış farklarından dolayı, verilen 20 problem arasından yedisini daha önemli olarak değerlendirdiğini ortaya koyan ANOVA sonuçları sunulmuştur. Tribe'ın (2009) turizm araştırmalarının sınıflandırmasına göre, bu 7 problem üç farklı grupta incelenmiştir: estetik ile ilişkili (Problem \#8), gerçeklikle ilişkili (Problem \#15, \#16), ve erdemle ilişkili (Problem \#4, \#5, \#7 ve \#13). Bu incelemeye ait sonuçlar Tablo 3'te görülmektedir. Yap1lan karşılıklılık analizi sonucunda, problemin yaptığ1 çağrışım ile bu yedi problem arasında bir ilişki olduğu saptanmıştır (Şekil 4a-c). Turizm problemlerini labirent/diğer, zorluk/bulmaca, ve engel/boşluk/çelişki olarak niteleyen katılımcılar, problemlerin araştırma için önemini sırasıyla olumsuz, nötr ve olumlu olarak değerlendirmişlerdir. $\mathrm{Bu}$ açıdan bakıldığında, problemin yaptığı çağrışımın, problem seçimi ile ilişkili olduğu görülmektedir $(\mathrm{b}=$ $.298, \mathrm{~F}=30.884, \mathrm{p}<.001$; düzeltilmiş $\mathrm{R} 2=.061, \mathrm{~F}$ $=3.247, \mathrm{p}<.01)$. Şekil 4d'de diğer ilişkiler görülmektedir: boşluk/bulmaca ile gerçeklik-estetik/gerçeklik-erdem, diğer ile erdem, zorluk/labirent ile gerçeklik-erdem-estetik/gerçeklik, engel/çelişki ve erdem/estetik, ve engel ile estetik. Yine de problemin yaptığ etkilememektedir.

\section{TARTIŞMA}

Ana sonuçların açıklanması/yorumlanması: Ampirik çalışma sonucunda: (a) katılımcıların çoğunluğu turizm problemlerini, zorluklar ve çelişkiler olarak ifade etmişlerdir; (b) problemin yaptığı çağrışımın hem kişisel hemde çevresel TPÖ'den etkilendiği ve (c) problemin yaptığı çağrışımın hem problemin değerlendirilmesini hem de problem seçimini etkilediği bulunmuştur. Bu bulgular ayrıca, kuramsal modelde yer alan TPÖ, TPD ve TPS arasındaki ilişkileri de destekleyici niteliktedir. Bu çalışmada tanımlanmış olan ilişkilerin özü, modelde yer alan bağımlı ve bağımsız değişkenlerin değerlerinin sistematik ilişkileri göz önüne alınarak yorumlanmalıdır. Toplamda yedi ilişki grubu bulunmaktadır (Tablo 4). Bu grupların benzerlikleri ve altlarında yatan aksiyolojik ve pragmatik görüşler göz önüne alınarak (Guba 1990; Guba ve Lincoln 2005; Habermas 1978), temelde daha büyük üç ilişki grubu tanımlanmıştır. Bunlar (Tablo 4); yapısalcılık (Grup 1 ve 2), post-pozitivizm (Grup 3, 4 ve 5), ve pragmatizm (Grup 6 ve 7).

Yapısalcılık grubu, turizm araştırmasının turizm fenomenini anlamaya ve onu etkilemeye odaklanmış olması gerektiğine inanan araştırmacılardan oluşmaktadır. Bu araştırmacılar turizm fenomeninin ya tarih, iktisat, etik ve cinsiyet gibi faktörlerden etkilendiğine ya da bu fenomenin tamamen insanlar tarafından oluşturulduğuna ve konularla araştırmacıların birbirinden ayrı tutulmaması gerektiğine inanmaktadırlar. Bu araştırmacılar yerel düzeyde tanınan ya da sıradan Çin üniversitelerinde çalışmaktadırlar. Dahası bu araştırmacılar kurumsal/ulusal boyutlu araştırma çevresine dair

Tablo 3. Farklı Problem Tanımı Grupları Arasından Seçilen 20 Test Probleminin Değerlendirilmesi

\begin{tabular}{|c|c|c|c|c|}
\hline Problema & Kategori & Ortalamab & $F$ & $\begin{array}{r}\text { Sig. } \\
\text { (2-uçlu) }\end{array}$ \\
\hline \#8 Turizmin sunduğu manzaranın monotonluğu ve buna yönelik çözümler. & Estetik & 3.679 & 4.781 & .000 \\
\hline \#15 Kültürel çevre ve destinasyon imajı algısı. & Gerçeklik & 3.670 & 2.195 & .045 \\
\hline \#16 Turizmin yeni yeni ortaya çıkan bir disiplin olarak doğası ve yeri. & Gerçeklik & 3.981 & 2.296 & .036 \\
\hline \#4 Duyarlı turist davranışı ile sürdürülebilir turizm kalkınması arasındaki ilişki. & Erdem & 4.019 & 2.260 & .039 \\
\hline \#5 Çin'in, turizm ile ilgili hukuki düzenlemeleri. & Erdem & 3.920 & 3.159 & .006 \\
\hline $\begin{array}{l}\text { \#7 Çinli turistlerin yabancı destinasyonda yaptıkları uygun olmayan davranışlar } \\
\text { ve buna karşı alınabilecek önlemler. }\end{array}$ & Erdem & 3.241 & 3.121 & .006 \\
\hline \#13 Turizm işletmeleri için sorumluluk sistemi kurmak. & Erdem & 3.726 & 2.928 & .009 \\
\hline
\end{tabular}

Not: aSözcük sınırından dolayı yalnızca anlamlı olan sonuçlar sunulmuştur (Raporlanmamış olanlar istek üzerine temin edilebilirler). bBu problemlerin önem dereceleri 5'li Likert ölçeği ile ölçülmüştür (1= Hiç Önemli Değil, 5= Çok Önemli). 

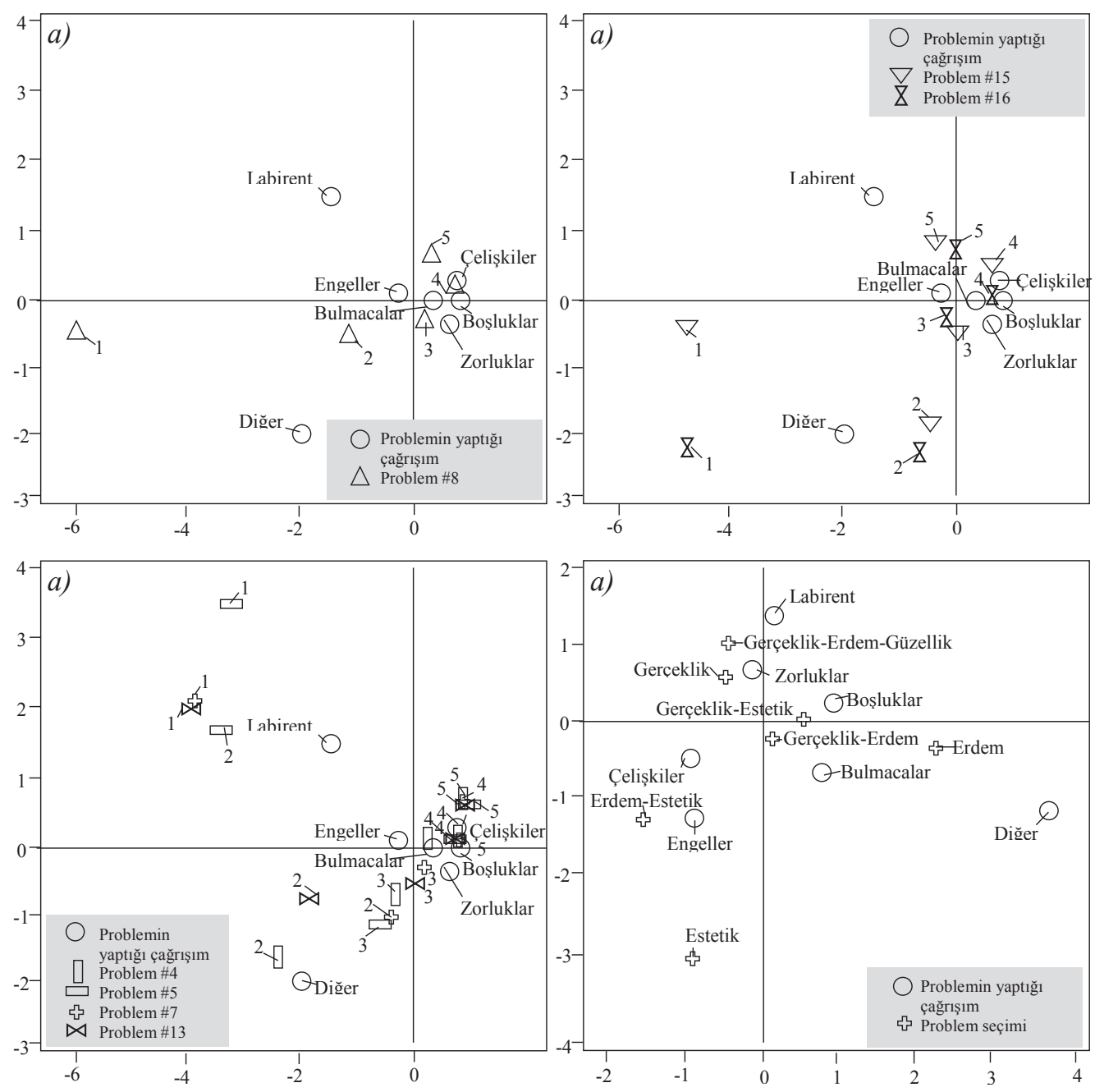

Not: Şekil 4a,b,c'de test problemlerinin önem dereceleri 5'li Likert ölçeği ile ölçülmüştür (1= Hiç Önemli Değil, $5=$ Çok Önemli).

Şekil 4. Problemin Yaptı̆̆ Çağrışımın, Araştırma Tetikleyicisi Olarak Problem Üzerindeki Etkileri

olumsuz tutumlar içerisindedirler ve turizm problemlerini, turizm araştırmasının başa çıkması gereken zorluklar olarak tanımlamaktadırlar. Yapisalcllık grubu ikinci olarak, gerçeklik/erdem/estetik problemlerini, sırasıyla nötr'den olumluya doğru değerlendirmişlerdir. Ayrıca gerçekle ilintili turizm problemlerine, araştırmaya başladıkları ilk dönemlerde ağırlık vermişlerdir. Post-pozitivist ve pragmatis gruplarda da dağılım benzer şekildedir.

Peki, TPÖ, TPD ve TPS arasındaki sistematik iliş- kiler nasıl tanımlanabilir? Sonuç olarak, araştırma sonuçları problemolojinin öncülü-doğası-sonuçları mantığının, verilen araştırma çerçevesi dâhilinde bir dizi araştırma prosedürü ile yakalanarak somutlaştırılmış hali olarak görülebilir. Bu şekilde, herbirinin sonuçlara ayrı ayrı nasıl etki ettiğini tartışmak verimli olmasa da, ortaya konan örnekler faydalıdır. Ontolojik ve epistemolojik inanışlar arasındaki eşleșmelerin, paradigma bileșenleri arasındaki eğilime öz-örgütlenme yönünde etki etmesi 
gerekmektedir. Guba'ya $(1990,2005)$ göre, naif gerçekçilik nötralizm ile, nesnelcilik ise iç-nesnelcilik ile eşleşmeye meyillidir. Bu tarz bir meyil, bu çalışmada karşılaşılan benzer yapıları açıklayabilir.

Araştırma bağlamının karakteristikleri; çalış1lan kurumun çeşidi ile düzen(üniversite)/katılık (Çin)/düzen (Çin) arasındaki bağ ve çalışılan kurumun çeşidi ile aksiyolojik/ontolojik/epistemolojik inanış arasındaki bağ yardımıyla açıklığa kavuşturulabilir. Örnek olarak Çin'de faaliyet gösteren “985"ler olarak bilinen üniversiteler - “211"ler/s1radan üniversiteler ile karşılaştırıldığında - daha sıkı bir araştırma yönetimine, daha fazla araştırma kaynağına ve daha fazla akademik üne sahiptirler. Bu durum "985" lerde çalışan turizm araştırmacılarının, çalıştıkları kurumu neden daha organize, daha düzenli ve Çin'deki araştırma çevresini daha katı olarak tanımladıklarını anlamamıza yardımcı olabilir (Bu yukarıda bahsedilen bağların ilkidir). Diğer bağ ise üç alt faktör ile açıklanabilir: (a) "985"lere dâhil olan üniversiteler sayıca en çok turizm araştırmasını özellikle teorik çalışmaları yapan üniversitelerdir çünkü bu üniversiteler diğerlerine nazaran daha araştırma odaklıdır; (b) turizm araştırması pozitivizm ve post-pozitivizm tarafından domine edilmektedir (ör., Ateljevic vd. 2007; Phillimore ve Goodson 2004; Platenkamp ve Botterill 2013); ve (c) "985"lerde görev yapan araştırmacılar ülkedeki diğer kurumlarda görev yapan araştırmacılara nazaran daha güçlü bir dürtü ile ayakta kalabilmek için, kurallara uymaya ve uluslararası turizm bilgisi üretimine katılmaya, daha fazla çalışmaktalardır.

Bunlara ek olarak, seçilen araştırma yöntemi de (ör. modelleme, ölçüm, örnekleme ve analitik araçlar) TPÖ, TPD ve TPS arasındaki ilişkilerin anlaşılmasına katkıda bulunmaktadır. İstatistikler, farklı yöntemlerin seçilmesine göre değişim gösterecektir. Örnek olarak, Tablo 2'de verilen değerler, kategorik regresyon analizi ile incelendiğinde sonuçlar bir parça değişecektir çünkü bu yöntem doğrusal regresyon analizi kadar sağlam sonuçlar vermeyecektir. Bu çalışmada sistematik ilişkileri anlayabilmek için faktörler göz önüne alınmamıştır, hatta bir dereceye kadar bu tesadüfte olabilir. Bu, problemin yaptığı çağrışım ile problem değerlendirme/ seçimi arasında oluşan daha az doğrusal eşleşmelerin boyutlarını rasyonalize edebilir.

\begin{tabular}{|c|c|c|c|c|c|c|c|c|c|c|}
\hline \multirow[t]{2}{*}{ Grup } & \multicolumn{3}{|c|}{ Kişisel TPÖa } & \multicolumn{4}{|c|}{ Çevresel TPÖ } & \multirow{2}{*}{$\begin{array}{c}\text { TPD (Birincil) } \\
\text { Problemin } \\
\text { yaptığı } \\
\text { çağrışım }\end{array}$} & \multicolumn{2}{|c|}{$\begin{array}{l}\text { TPS (Araştırma tetikleyicisi olarak } \\
\text { problem) }\end{array}$} \\
\hline & Aksiyolojik inanış & Ontolojik inanış & Epistemolojik inanış & Kurum türüb & $\begin{array}{l}\text { Düzen } \\
\text { (Üniv.) }\end{array}$ & $\begin{array}{c}\text { Katılık } \\
\text { (Çin) }\end{array}$ & $\begin{array}{l}\text { Düzen } \\
\text { (Çin) }\end{array}$ & & $\begin{array}{c}\text { Problem } \\
\text { değerleme }\end{array}$ & Problem seçimi \\
\hline 1 & Pratik & $\begin{array}{l}\text { Tarihsel } \\
\text { materyalizm }\end{array}$ & $\begin{array}{l}\text { Öznelerarasılık; } \\
\text { Revize nötralizm }\end{array}$ & $\begin{array}{l}\text { Sıradan Üniv.; } \\
\text { "211" üniv. }\end{array}$ & $4 ; 3$ & $3 ; 2$ & $2 ; 3$ & $\begin{array}{l}\text { Zorluklar } \\
(\% 39,71)\end{array}$ & 3 & $\begin{array}{l}\text { Gerçeklik-Erdem- } \\
\text { Estetik; Gerçeklik }\end{array}$ \\
\hline 2 & Pratik & Nesnelcilik & Revize nötralizm & “211” üniv. & / & I & I & $\begin{array}{c}\text { Boşluklar } \\
(\% 6,7)\end{array}$ & $4 ; 5$ & $\begin{array}{l}\text { Gerçeklik-Estetik; } \\
\text { Gerçeklik-Erdem }\end{array}$ \\
\hline 3 & $\begin{array}{l}\text { Teknik (zayıf); } \\
\text { Teknik (güçlü) }\end{array}$ & Naif gerçekçilik & $\begin{array}{l}\text { Nötralizm; } \\
\text { Etkileşimcilik }\end{array}$ & “985” üniv. & $5 ; 6$ & 4 & $4 ; 6$ & $\begin{array}{l}\text { Çelişkiler } \\
(\% 21,05)\end{array}$ & $4 ; 5$ & Erdem-Estetik \\
\hline 4 & $\begin{array}{l}\text { Teknik (zayıf); } \\
\text { Teknik (güçlü) }\end{array}$ & Naif gerçekçilik & $\begin{array}{l}\text { Nötralizm; } \\
\text { Etkileşimcilik }\end{array}$ & “985” üniv. & $6 ; 7$ & $4 ; 6$ & $4 ; 6$ & $\begin{array}{c}\text { Bulmacalar } \\
(\% 13,4)\end{array}$ & $3 ; 4$ & Gerçeklik-Erdem \\
\hline 5 & $\begin{array}{l}\text { Teknik (zayıf); } \\
\text { Teknik (güçlü) }\end{array}$ & Naif gerçekçilik & $\begin{array}{l}\text { Nötralizm; } \\
\text { Etkileşimcilik }\end{array}$ & “985” üniv. & $5 ; 6$ & 4 & $4 ; 6$ & $\begin{array}{c}\text { Labirentler } \\
(\% 6,7)\end{array}$ & $2 ; 1$ & $\begin{array}{l}\text { Gerçeklik-Erdem- } \\
\text { Estetik }\end{array}$ \\
\hline 6 & Karışık & Görecilik & Görecilik & $\begin{array}{l}\text { Diğer; "211” } \\
\text { üniv. }\end{array}$ & I & I & I & $\begin{array}{l}\text { Engeller } \\
(\% 9,09)\end{array}$ & 5 & $\begin{array}{l}\text { Erdem-Estetik; } \\
\text { Estetik }\end{array}$ \\
\hline 7 & Karışık & Görecilik & /c & Diğer & 1 & 1 & 1 & $\begin{array}{c}\text { Diğer } \\
(\% 3,35)\end{array}$ & $2 ; 1$ & Erdem \\
\hline
\end{tabular}

Not: aTPD $=$ Turizm Probleminin Doğası, TPÖ = Turizm Probleminin Öncülü, TPS = Turizm Probleminin Sonucu. b“985” üniv.= Çin'deki üst düzey üniversiteler, "211" üniv.= Çin'deki ikinci üst düzey üniversiteler. cSonuçlar Şekil 3a,3b,3c'ye dayanmaktadır. dBazı hücrelerde iki değişken değerleri bulunmaktadır çünkü yapılan karşılıklılık analizi sonucunda bu tip hücrelerde değişken değerleri benzer/yakın çıkmıştır. Buna rağmen ilk sırada gelen değer ana bağımlı(bağımsız) değişken veya değişkenlere aittir.

Cilt 26 - Sayı 1 
TP için öneriler: Bu çalışmanın öncelikli hedefi Turizm Problemolojisi'nin oluşturulmasıdır. Yukarıda sunulan sonuçlar ışığında bu hedefe yönelik üç öneri geliştirilmiştir. Turizm problemlerini kuramsallaştırmak açısından ilk girişim olan bu çalışma ile bu olasılığın yerinde olduğu ortaya konulmuştur. Bununla birlikte çalışmanın varsayımı bir soruya cevap bulamamıştır: henüz problemolojinin yeni yeni ortaya çıkmakta olduğu anlayışına rağmen, turizm problemolojisini oluşturmak mümkün müdür (Lin, 1990; Lin, 1991, 2005)? Neyse ki bu varsayım teyit edilmiştir. Kavramsal TP modeli, bu çalışmada yapılan felsefi öngörüler ve ampirik doğrulamalar sayesinde yeteri kadar ampirik desteğe sahiptir. Ortaya konan model, bu çalışmanın çoklu karşılaştırmalar ${ }^{15}$ vasıtası ile doğrulanmasını önermektedir. İkinci olarak, bir proje olan TP'nin oluşturulmasının henüz tamamen sonuçlanmadığının da eklenmesi gerekmektedir. Bu çalışma ortaya koyduğu gelişmelere rağmen, modeli tamamı ile belirleme noktasında (üçüncü/dördüncü kavramsal düzeyde) başarısız olmuş ve yalnızca temel düzeyde TPÖ, TPD ve TPS arasındaki ilişkileri test etmiştir. Üçüncü ve son olarak da, TP ile ilgilenen araştırmacıların çoğulcu bir tutum içinde olmaları tavsiye edilmektedir. Daha önce de belirtildiği gibi, bu çalışmanın sonuçları, çeşitli faktörler ile açıklanabilir (ör. problemolojinin mantığı, araştırma bağlamı, araştırma yöntemleri, gizil ve rassal durumlar). Bu faktörlerin değişkenliği TP'nin kendi içinde de tekil olamayacağını göstermektedir.

Problemoloji için önerileri: Bu çalışma ile problemolojinin kuramsal yapısına yönelik bazı öneriler getirilmiştir. Problemoloji terimi ilk kez 1980'lerde kullanılmıştır ve henüz tam olarak yerleşmiş değildir (Lin, 2005). Problemlerin doğasını parça parça inceleyen çalışmalar ve problemlerin doğası üzerindeki uzlaşı eksikliği iki temel engeldir. İlk sorunla başa çıkmak için problem araştırmalarının

\footnotetext{
15 Çevirmenin notu: Çoklu karşılaştırma (post hoc) testleri, gruplararası farkın olduğu durumda, farklılığın hangi gruptan kaynaklı olduğunu tespit eden istatistik testlerdir. Çoklu karşılaştırma testleri çok faktörlü bir deneyde veya araştırmada, varyans veya regresyon analizi gibi istatistiksel analizler sonucunda genel bir anlamlılık belirlendikten sonra hangi karşılaştırmaların anlamlı bir fark gösterdiğini bulmak amacıyla yapılmaktadır (ör. LSD, Sidak, Bonferroni, Tukey HSD, Hochberg's GT2, Gabriel, Scheffe) (Ayrıntılı bilgi için bkz. Köklü, N., Büyüköztürk Ş. ve Bökeoğlu, Ç.Ö. (2006). Sosyal bilimler için istatistik. Ankara: PegemA).
}

öncü-doğa-sonuç çerçevesi içerisinde planlanması önerilmektedir. Bahsedilen çerçeve problemoloji yazını temel alınarak oluşturulmuştur. Bu çerçeve problemolojistler tarafından ortaya konmamış olsa da, bu çalışma ile -özellikle de parça parça problem araştırmalarını anlamlı bilgi blokları halinde yapılandırmak açısından- kullanışlı olduğu kanıtlanmıştır.

İkinci engeli aşmak için ise felsefe ile bilim arasındaki diyaloğun arttırılması önerilmektedir. Şimdiye kadar bilim felsefecileri, problemolojiye en çok katkıyı yapan araştırmacılardır (Lin, 2005; Zhang, 2005). Ayrıca felsefe de geniş kabul görmüş bir kural da vardır; henüz çözülmüş olandan daha fazla problem vardır (Rosenberg, 2005). Filozoflar iddiaları haklı çıkarmak için - farklı fikirlerin ortaya çıkmasinı engellemekten ziyade cesaretlendiren- tartışmaya ağırlık verirler. Bu durumdan kaçınmak için bilimsel bakış açısı önemlidir. Çünkü bilim insanları, filozoflardan farklı olarak, bir kuramsal iddiayı kabul etmeden önce onun doğruluğunu sinayabilmek için ampirik verilerin peşine düşerler. $\mathrm{Bu}$ iddialar ampirik açıdan test edilebilirlerse, belki bu sayede problemlerin doğası üzerindeki tartışmalar azaltılabilecektir. Bu düzeltmeler mevcut çalışmada da görülmektedir. Turizm araştırmacıları, problemoloji yazınından derlenen altı tanım arasından zorlukları ve çelişkileri tercih etmiştir. Bu tarz bir yargıya yalnızca felsefi tartışmalar yaparak ulaşmak zordur. Bunun yanında problemolojinin gelişmesi için hem filozofların hem de bilim insanlarının katkıda bulunması gerekmektedir.

Turizm bilgisi üretiminin yeniden düşünülmesi üzerine öneriler: Daha önceki çalışmalarda turizm bilgisi üretiminin, paradigmaya bağlılık, araştırma yöntemleri, disipline dayalı arka plan, araştırmacı ağ1 ve yeni teknolojiler gibi faktörlerden etkilendiğinden bahsedilmiştir. Bu çalışmada, araştırma problemleri özelinde, hem kişisel hemde çevresel TPÖ'nün -fakat özellikle çevresel TPÖ'nün- TPD/ TPS'yi etkilediği bulunmuştur (Tablo 2 ve 3). Araştırma problemi, turizm bilgisi üretimi süreçlerinin faktörleri arasındadır. TPÖ’ler ise bu süreçleri etkileyen faktörleri içine almaktadır. Bu tip faktörler farklı düzeylerde önem arz edebilirler ve tek tek etkilemekten ziyade toplu halde etkilerler. Bu çalışma TPÖ, TPD ve TPS arasındaki ilişkileri ortaya çıkararak, turizm bilgisi üretiminin kendisinin de aslında karmaşık bir sistem olduğunu öne sürmek- 
tedir. Bu tarz bir sistemde, araştırma problemleri, turizm bilgi üretimini, etki faktörlerine bağlayan, etki sahibi bir alt sistem ya da görünmeyen bir etken olarak rol oynarlar. Turizm problemleri hakkında daha fazla bilgiye sahip olmak, turizm bilgisi üretimini etkileyen faktörler üzerindeki anlayışı da geliştirebilir.

Uygulamaya dönük öneriler: Bu çalışma bir grup Çinli araştırmacıyı nesne olarak incelemiş ve bu sebeple de onlara (ve onların temsil ettiği araştırmacılara) yönelik öneriler getirmiştir. Araştırmacılara yönelik en önemli görülen öneri, araştırmac1ların yürüttükleri turizm araştırmaları içerisindeki problem sisteminin farkında olmaları gerekliliğidir. Bu sebeple, bu sistem içerisindeki anahtar bileşenlere ait yeterli bilgilerin edinilmesi gerekmektedir. Örneğin paradigma bilgisi, araştırmacılara paradigma körlügünü ve felcini ortadan kaldırmaya yardım edebilecektir. Bu çalışma ile Çin bağlamında şu öneriler ileri sürülmüştür: (a) önde gelen üniversitelerde görev yapan turizm araştırmacıları post-pozitivizmin hâkimiyetini kabul etmeli ve turizm bilgisini dar/tek bir paradigmaya bağlı kalmadan üretmelidir; (b) daha düşük düzeyli kurumlarda çalışan araştırmacılar ise tercih ettikleri paradigmayı post-pozitivizm ile dengelemelidirler.

Turizm araştırması yapılarının (ör. kurumlar içindeki araştırma komiteleri, Çin Ulusal Turizm İdaresi ve Çin Ulusal Sosyal Bilimler ve Doğa Bilimleri Kurumu), çevresel faktörlerin turizm problemleri üzerindeki güçlü etkisini göz önüne alarak, turizm araştırmalarının değerlendirmelerini sıkılaştırmalı ve turizm araştırmacıları için daha sağlıklı ve daha simülatif bir dış ortam yaratmalıdırlar. Ulusal düzeyde, Çin'in eğitim kurumlarının tabakalara ("985"ler - "211"ler-Sıradan üniversiteler-Kolej/diğer) ayrılmış olması yeniden gözden geçirilmelidir. Bu hiyerarşik sistem araştırma emeğinin dağıtılması ve daha fazla bilgi üretilmesi açısından verimli olsa da, yalnızca belirli problem tiplerini desteklemeye meyillidir. Bunun sonucu olarak ise yanlı bilgi üretilmektedir. Yukarıda sayılan durumlar, araştırma idaresi yapılarının ve kanun düzenleyicilerini ilgilenmesi gereken konulardır.

\section{SONUÇ}

Bu çalışma genel anlamda turizm bilgi üretiminin tüm süreçlerinde önemli bir rol oynayan turizm problemlerini anlamaya çalışmıştır. Çalışmanın hedefi, turizm problemlerinin doğasını, öncülünü ve sonuçlarını kendine has, sistematik ve derinlemesine bir şekilde çalışmak anlamına gelen turizm problemolojisini oluşturmaktır. Çalışma iki temel aşama şeklinde uygulanmıştır. İlk aşamada, turizm problemolojisinin teorik modeli henüz yeni yeni ortaya çımakta olan problemoloji yazınından (genel olarak bilim felsefesi) türetilmiştir. İkinci aşamada, İkinci aşamada ise model Çin'in araştırma topluluğunu temsil edecek geçerli bir örneklem oluşturan bir grup araştırmacı üzerinden test edilmiştir.

Turizm araştırmacıları turizm problemlerini, çözülmesi gereken çatışmalar ve aşılması gereken zorluklar olarak tanımlanmışlardır. Bu tanımlamalar doğal olarak hem kişisel (aksiyolojik, ontolojik ve epistemolojik inanışlar) hem de çevresel (kurum çeşitleri ve araştırmacıların algıları) birçok faktör tarafından etkilenmektedir. Dahası, araştırmacıların turizm problemlerinin anlama düzeyleri, çalışılan turizm problemlerinin çözüm seçimi ve değerlendirilmesi üzerinde dikkate değer bir etkide bulunmaktadır (kaldı ki bu da turizm araştırmasının ilk aşamasını oluşturur). Bir kere problemler belirlendiğinde, bilginin doğasını (çözülmüş problemler olarak) ortaya koyacak (Laudan 1977; Popper 1972) bu başlangıç aşaması, tüm araştırma süreci için hayati bir rol üstlenecektir.

Bu çalışmanın en önemli katkısı, turizm sorunlarını bir bütün olarak ele alan öncü bir çalışma olmasıdır. Çalışmada bir problem sistemi içerisindeki çeşitli bileşenler açılanmış ve bu bileşenler arasındaki temel ilişkiler tanımlanmışıı. Bu bulgular turizm problemleri üzerine bir yarı-kuram ortaya koymuştur. Bu tarz bir yarı-kuram geliştirilmeye ihtiyaç duyuyor olsa da, gelecek araştırmalara bir temel oluşturmaktadır. Ayrıca bu çalışma problemoloji için de anahatlar sunmaktadır. Problemolojinin (turizm problemolojisini de içerecek şekilde) yapılandırılması felsefi öngörüler ile ampirik bulgular birleştirilmez ise zorlayıcı olacaktır. Bu çalışma -turizm problemolojisini oluşturma anlamında- yalnızca öne sürülen iddiaların doğruluğunu kanıtlamakla kalmamış, aynı zamanda bunun nasıl gerçekleştirilebileceğini de ortaya koymuştur. $\mathrm{Bu}$ katkı turizm bilgisinin artan refleksivitesi ile alakalıdır. Bu çalışma, problemleri ve paragdimaya bağll1ık gibi etki sahibi faktörleri analiz ederek, turizm bilgisi üretiminin arkasındaki üstü kapalı dü- 
zeneğe 1şı1k tutmuştur. Dahası, turizm problemolojisinin kuramsal modelinin farklı durumlara göre spesifikasyonu, turizm araştırması ile onun çeşitli öncüllerinin arasındaki bağın da aydınlanmasını sağlayacaktır.

Daha önce bilinmeyen bir alana girdiğinden dolayı bu çalışmanın karşılaştığı bazı sınırlılıklar vardır. Modelin kendi karmaşıklığ 1 ve problemoloji yazınından beklenen ön desteğin eksikliğinden dolayı, kuramsal modelin dördüncü ve beşinci düzey yapıları henüz tam anlamılla belirlenememiştir. Ek olarak modelin ampirik sınaması da tamamlanamamıştır. Metodolojik açıdan, örnekleme yöntemi tam anlamiyla rassal değildir ve Çin anakarasında görev yapan bir grup araştırmacıyı kapsamaktadır. Bunların dışında farklı yapılara sahip araştırmacıların araştırmaya dâhil edilmesinin, araştırma modeli üzerinde etkisi olabilir. Çalışma kapsamında karmaşık ve tahmin edilmesi zor değişkenlerin ölçülmesi, katı güvenilirlik ve geçerlilik tartışmalarının yapılmasını engellemektedir.

Gelecekteki çalışmalar açısından, yukarıdaki sınırlılıklar adres gösterilmektedir. Çalışma kapsamında geliştirilmiş olan kuramsal modelin farklı koşullar altında da test edilmesi gerekmektedir. Özellikle birkaç alan üzerinde düşünülmesi gerekmektedir: (a) modelin sürekli ölçekler ile nicelikselleştirilmesi ya da modelin basitleştirilerek daha büyük model düzenlemelerinin sağlanması ve (b) turizm problemlerinin doğasının ve içyapısının daha detaylı olarak anlaşılabilmesi için derinlemesine görüşme gibi niteliksel tekniklerin de kullanılması gerekmektedir. Bu çalışma ile turizm problemolojisinin henüz sınırları tam olarak çizilmemiş topraklarına mecera dolu bir seyahat yapılmıştır. Bu çabalar ile turizm araştırmacılarının ilgisini problemleri sadece çözmekten çok, problemleri ve bu problemlerin turizm araştırmasına yaptığı etkileri anlamaya yöneltebilmek umulmaktadır.

\section{TEŞEKKÜR}

Bu çalışma Çin Ulusal Doğa Bilimleri Kurumu tarafından desteklenmiştir [Proje no: 71202094]. Ankete katılan tüm araştırmacılara, özellikle de yanitladıktan kısa bir süre sonra vefat eden Profesör Yuming Wang'a teşekkür ederiz. Ayrıca, Profesör Honggang $\mathrm{Xu}$ ve diğer tüm anonim inceleyicilere teşekkür ederiz.

\section{KAYNAKÇA}

Ateljevic, I., Pritchard, A. ve Morgan, N. J. (Ed.). (2007). The Critical Turn in Tourism Studies. Oxford, UK: Elsevier.

Benckendorff, P. ve Zehrer, A. (2013). A Network Analysis Of Tourism Research, Annals of Tourism Research, 42: 121-149.

Collingwood, R. G. (1948). The Idea Of History. Oxford, UK: Clarendon Press.

Cooley, L., ve Lewkowicz, J. (2003). Dissertation writing in practice: Turning ideas into text. Hong Kong: Hong Kong University Press.

Cooper, C. (2006). Knowledge Management And Tourism, Annals of Tourism Research, 33 (1): 47-64.

Copi, I. M. ve Cohen, C. (2005). Introduction to Logic (12. Bs.). Upper Saddle River, NJ: Pearson.

Davidson, J. E. ve Sternberg, R. J. (Ed.). (2003). The Psychology Of Problem Solving. Cambridge. Büyük Britanya: Cambridge University Press.

Dewey, J. (1910). How We Think. Büyük Britanya, Londra: Heath.

Dewey, J. (1965). Problems of Men. Shanghai: Shanghai People's Press [Çince].

Einstein, A. ve Infeld, L. (1961). The Evolution Of Physics: The Growth Of Ideas From Early Concepts To Relativity And Quanta (2. Bs.). Cambridge, UK: Cambridge University Press.

Franklin, A. ve Crang, M. (2001). The Trouble With Tourism And Travel Theory?, Tourist Studies, 1 (1): 5-22.

Gibbons, M. (1994). The New Production of Knowledge: The Dynamics Of Science And Research in Contemporary Societies. Londra, UK: SAGE Publications.

Giere, R. N. (2004). How Models Are Used To Represent Reality. Philosophy of Science, 71 (5), Supplement, 742-752.

Guba, E. G. (Ed.). (1990). The Paradigm Dialogue. Londra, UK: Sage.

Guba, E. G. ve Lincoln, Y. S. (2005). Paradigmatic Controversies, Contradictions, And Emerging Confluences. İçinde, N. K. Denzin ve Y.S. Lincoln (Ed.), Handbook of qualitative research (3. Bs., 191-215). Thousand Oaks: Sage Publications.

Habermas, J. (1978). Knowledge and Human Interests (2. Bs.). Londra, UK: Heinemann.

Hair, J. F. J., Black, W. C., Babin, B. J., Anderson, R. E. ve Tatham, R. L. (Ed.). (2010). Multivariate Data Analysis (7. Bs.) Upper Saddle River, N.J.: Pearson.

Hall, C. M. (2004). Reflexivity and Tourism Research. İçinde, J. Phillimore ve L. Goodson (Ed.), Qualitative Research in Tourism: Ontologies, Epistemologies And Methodologies (ss. 137-155). Londra, UK: Routledge.

He, H. (1983). An Introduction to Artificial Intelligence. Beijing: Air Force Engineering Institution Press [Çince].

Hilbert, D. (2009). Mathmatical Problems (W. Li ve X. Yuan, Trans.). Dalian: Dalian University of Technology Press [Çince].

Hodges, W. (1993). Model Theory. Cambridge, UK: Cambridge University Press.

Hurley, P. J. (2008). A Concise Introduction To Logic (10. Bs.). Belmont: Thomson Wadsworth.

Kuhn, T. S. (1962). The Structure Of Scientific Revolutions. Chicago: University of Chicago Press.

Laudan, L. (1977). Progress and Its Problems: Toward a Theory of Scientific Growth. Berkeley, Calif.: University of California Press. 
Liburd, J. (2012). Tourism Research 2.0, Annals of Tourism Research, 39 (2): 883-907.

Lin, D. (1990). The Study Of Problemology and Definition Of Problems, Philosophical Studies, (4): 92-101 [Çince].

Lin, D. (1991). On the Aim Model of Scientific Progress. Social Sciences in China, 12 (4): 29-38.

Lin, D. (2005). Problem and Scientific Research: A Study Of Problemology. Guangzhou: Sun Yat-sen University Press [Çince].

Liu, Y. (Ed.). (1987). Epistemology and Methodology in Sciences. Beijing: Tsinghua University Press [Çince].

Luger, G. F. (2009). Artificial Intelligence: Structures And Strategies For Complex Problem Solving (6. Bs.). Boston: Pearson Addison- Wesley.

Lyotard, J.-F. (1984). The Postmodern Condition: A Report On Knowledge. Minneapolis, Minn.: University of Minnesota Press.

Meethan, K. (2001). Tourism in Global Society: Place, Culture And Consumption. Londra, UK: Palgrave.

Neuman, W. L. (2006). Social Research Methods: Qualitative And Quantitative Approaches (6. Bs.). Boston: Pearson.

Nowotny, H., Scott, P. ve Gibbons, M. (2001). Re-Thinking Science: Knowledge And The Public in An Age of Uncertainty. Cambridge, UK: Polity Press.

Patterson, M. E. ve Williams, D. R. (1998). Paradigms and Problems: The Practice Of Social Science in Natural Resource Management, Society and Natural Resources, 11 (3): 279-295.

Patterson, M. E. ve Williams, D. R. (2005). Maintaining Research Traditions On Place: Diversity of Thought And Scientific Progress, Journal of Environmental Psychology, 25 (4): 361-380.

Phillimore, J. ve Goodson, L. (Ed.). (2004). Qualitative Research in Tourism: Ontologies, Epistemologies And Methodologies. Londra, UK: Routledge.

Platenkamp, V. ve Botterill, D. (2013). Critical Realism, Rationality And Tourism Knowledge, Annals of Tourism Research, 41: $110-129$.

Popper, K. R. S. (1959). The Logic Of Scientific Discovery. Londra, UK: Hutchinson.

Popper, K. R. S. (1972). Objective Knowledge: An Evolutionary Approach. Oxford, UK: Clarendon Press.
Popper, K. R. S. (1999). All Life is Problem Solving (P. Camiller, Trans.). Londra, UK: Routledge.

Popper, K. R. S. (2001). Emancipation Through Knowledge II (J. Fan ve B. Li, Trans.). Hangzhou: China Fine Art Academy Press [Çince].

Ritchie, B. W., Burns, P. M. ve Palmer, C. A. (Ed.). (2005). Tourism Research Methods: Integrating Theory With Practice. Oxfordshire, UK: CABI Publishing.

Rosenberg, A. (2005). Philosophy of Science: A Contemporary Introduction (2. Bs.). New York: Routledge.

Rosenberg, A. (2008). Philosophy of Social Science (3. Bs.). Boulder, CO: Westview Press.

Russell, B. (1922). The Problem of China. London, UK: Allen \& Unwin.

Simon, H. A. (1981). The Sciences Of The Artificial (2. Bs.). Cambridge, USA: MIT Press.

Sternberg, R. J., ve Spear-Swerling, L. (1996). Teaching for Thinking (1. Bs.). Washington, DC: American Psychological Association.

Toulmin, S. E. (1972). Human Understanding. Oxford, UK: Clarendon Press.

Tribe, J. (Ed.). (2009). Philosophical Issues in Tourism. Bristol, UK: Channel View Publications.

Tribe, J. (2004). Knowing about Tourism: Epistemological İssues. İçinde, J. Phillimore ve L. Goodson (Ed.), Qualitative Research in Tourism (ss. 46-62). Londra, UK: Routledge.

Xiao, H., Jafari, J., Cloke, P. ve Tribe, J. (2013). Annals: 40-40 Vision, Annals of Tourism Research, 40: 352-385.

Xiao, H. ve Smith, S. L. J. (2006). The Making Of Tourism Research: Insights From A Social Sciences Journal, Annals of Tourism Research, 33 (2): 499-507.

Xiao, H. ve Smith, S. L. J. (2007). The Use Of Tourism Knowledge: Research Propositions, Annals of Tourism Research, 34 (2): 310-331.

Zhang, Z. (2005). The Philosophical Studies On "Problems". Beijing: Renmin University Press [Çince]. 